\title{
Rare Earth Elements Enrichment in the Upper Eocene Tošići-Dujići Bauxite Deposit, Croatia, and Relation to REE Mineralogy, Parent Material and Weathering Pattern
}

\author{
Nenad Tomašić ${ }^{1, *}$, Andrea Čobić ${ }^{1}$, Matija Bedeković ${ }^{1}$, Slobodan Miko ${ }^{2}$ (®) Nikolina Ilijanić ${ }^{2}$, \\ Nikola Gizdavec ${ }^{2}$ and Mario Matošević ${ }^{3}$ \\ 1 Department of Geology, Faculty of Science, University of Zagreb, Horvatovac 102a, 10000 Zagreb, Croatia; \\ acobic@geol.pmf.hr (A.Č.); mbed8@hotmail.com (M.B.) \\ 2 Department of Mineral Resources, Croatian Geological Survey, Sachsova 2, 10000 Zagreb, Croatia; \\ smiko@hgi-cgs.hr (S.M.); nilijanic@hgi-cgs.hr (N.I.); ngizdavec@hgi-cgs.hr (N.G.) \\ 3 Exploration \& Production Laboratory, Subsurface \& Field Development, Exploration \& Production, \\ INA-Industrija nafte d.d., Lovinčićeva 4, 10000 Zagreb, Croatia; mario.matosevic@ina.hr \\ * Correspondence: ntomasic@geol.pmf.hr
}

\section{check for}

updates

Citation: Tomašić, N.; Čobić, A.; Bedeković, M.; Miko, S.; Ilijanić, N.; Gizdavec, N.; Matošević, M. Rare Earth Elements Enrichment in the Upper Eocene Tošići-Dujići Bauxite Deposit, Croatia, and Relation to REE Mineralogy, Parent Material and Weathering Pattern. Minerals 2021, 11, 1260. https://doi.org/10.3390/ $\min 11111260$

Academic Editor: Giovanni Mongelli

Received: 4 October 2021

Accepted: 7 November 2021

Published: 12 November 2021

Publisher's Note: MDPI stays neutral with regard to jurisdictional claims in published maps and institutional affiliations.

Copyright: (c) 2021 by the authors. Licensee MDPI, Basel, Switzerland. This article is an open access article distributed under the terms and conditions of the Creative Commons Attribution (CC BY) license (https:// creativecommons.org/licenses/by/ $4.0 /)$.
Abstract: Tošići-Dujići bauxite deposit, situated in Dalmatian inlands, Croatia, contains minor remaining bauxite reserves. The deposit lies on Lower Eocene foraminiferal limestone and is covered by Upper Eocene Promina sediments. Bauxite samples were analyzed for textural, mineralogical, and geochemical features in order to determine absolute REE abundances and their relation to mineralogy, as well as to devise the origin of REE enrichment and to trace weathering and bauxitization paths of the parent material. The samples show total REE abundances up to $3500 \mathrm{mg} / \mathrm{kg}$ with significant HREE enrichment in some cases. All samples are gibbsitic with hematite and anatase as major phases. Kaolinite occurs in most of the samples, and goethite, böhmite, and nordstrandite are minor phases. Monazite-(Ce) and xenotime-(Y) were identified as detrital REE minerals as well as authigenic florencite-(Ce). In the REE most abundant sample, REE are most likely bound to Fe- and Ti-oxide phases as suggested by correlation analysis. Chemical weathering proxies show intensive weathering. Geochemical and textural data imply that the REE enrichment is influenced by intensive weathering (CIA 97.87-99.26) of detrital material, and also by possible deposition/redeposition of residual material potentially derived and mobilized from various sedimentary rocks of the area.

Keywords: karst bauxite; rare earth elements enrichment; rare earth elements mineralogy; chemical weathering

\section{Introduction}

Bauxite deposits in the Oklaj area in inland Dalmatia, Croatia, are numerous. Many of them had been exploited in the past for local aluminum industry and export; however, exploitation ceased in 1990s. At some localities, bauxite reserves are largely exhausted, but some deposits are half-exploited or not exploited at all. Based on stratigraphic position, the deposits are mostly of Late Eocene age. The content of $\mathrm{Al}_{2} \mathrm{O}_{3}$ ranges from $40-54 \%$ and $\mathrm{SiO}_{2}$ content is from 1-17\% [1] (and references therein) making most of local bauxites exploitable for the aluminum industry. Generally, these bauxite deposits contain both gibbsite and böhmite, which are usually accompanied by hematite, goethite, anatase, and kaolinite.

Due to a persistent demand for rare earth elements (REE) in order to satisfy increasing technological and industrial needs, bauxite-related resources like red mud, a byproduct of alumina production, have been also considered as a potential source of these valuable metals [2]. Bauxites are usually enriched in REE relative to their hosting rocks due to the residual, frequently polygenetic character of bauxite material, which is derived from various rock precursors by weathering and/or aeolian/water transport, and local concentration of these metals in bauxite profile during bauxitization [3]. Bauxites of the Mediterranean 
area typically contain several hundred $\mathrm{mg} / \mathrm{kg}$ of total REE. Deeper horizons in many bauxite deposits are reported to contain more than $1000 \mathrm{mg} / \mathrm{kg}$, and such a significant REE content can trigger authigenic REE mineralization [4]. Minerals like florencite-(Ce), hydroxylbastnäsite-(Nd), bastnäsite-(Ce), goyazite-(Nd), and parisite-(Ce) are reported authigenic REE minerals in these bauxites [5]. Monazite-(Ce) and xenotime-(Y) are usually considered common detrital REE minerals in bauxites; however, some occurrences of these minerals were reported as authigenic [6].

Distribution of REE elements in a bauxite profile is controlled by prevailing conditions during weathering and bauxitiziation, and so is REE mineralization therein. Mobility of REE is largely influenced by $\mathrm{pH} / \mathrm{Eh}$ in a bauxite profile, affecting stability of REE phases as well as adsorption of REE on major mineral phases. Lower $\mathrm{pH}$ in a bauxite profile readily influences stability of authigenic REE minerals, but also promotes REE leaching out of detrital REE minerals like monazite-(Ce). This can further increase REE content in certain bauxite horizons and support REE mineralization [7]. Cerium behavior is interesting in this respect, since it can be oxidized to $\mathrm{Ce}^{4+}$, particularly in upper parts of a bauxite deposit. Thus, cerianite precipitation can occur that might cause Ce depletion in deposit fluids and lower parts of the deposit [8]. Establishment of a $\mathrm{pH}$-barrier close to carbonate bedrock in lower sections of a karst bauxite deposit can cause a $\mathrm{pH}$ increase and stabilization of REE carbonates like parisite-(Ce) [9], provided Ce is available. However, changes in water table and $\mathrm{pH} /$ Eh conditions can influence overall distribution of authigenic REE minerals in a bauxite profile [10]. Additionally, Fe oxides like goethite have been proven to influence REE distribution between the bauxite ooids and matrix due to adsorption of REE [8].

The aim of this study is to investigate distribution of REE elements in the Tošići-Dujići deposit, to relate it to the bauxite mineralogy, particularly REE minerals, and to devise chemical weathering intensity and bauxitization of parent material. Finally, geochemical and textural signatures are likely to give an insight into origin of the parent material, which is important for understanding possible REE enrichment in the bauxite deposit. Hereby, REE are considered a group of chemical elements comprising lanthanides and yttrium.

\section{Geological Background}

The bauxite deposit in Tošići-Dujići (also referred as Tošići 4 deposit) belongs to the former Čveljo Dolac exploitation field, where exploitation started in the mid-1970s and ceased in the early 1990s. There are just around 15,000 tons of unexploited bauxite left at the site. The deposit is situated in the Promina plain southwards of the Mt Promina and around $4 \mathrm{~km}$ southeast of the village Oklaj, between villages Dujići and Tošići (Figure 1). The Promina plain is famous for numerous bauxite bodies mainly of Eocene age. The Tošići-Dujići open exploitation pit is L-shaped with a maximal depth of around $25 \mathrm{~m}$, on average $70 \mathrm{~m}$ in width, and with composite elongation of around $250 \mathrm{~m}$. The deposit is situated in a syncline, a part of a folding and reverse faulting system stretching parallel to the Dinarides (NW-SE), which is a common feature of other similar bauxite deposits of this age in the area [11]. Bauxite material was deposited on Lower to Middle Eocene foraminiferal limestone. The foraminiferal limestone was continuously deposited in a shallow marine environment on older Paleogene Kozina limestones or is transgressive on Upper Cretaceous deposits, and, based of foraminiferal content, it is divided into alveolinid, miliolid, and nummulitid members [11]. When in contact with bauxite, the limestone is severely karstified and exposes a typical karst topography rough forms. The paleorelief is particularly visible in the western limb of the syncline, which accommodates the bauxite deposit. The hanging wall is composed of Upper Eocene sediments (Promina deposits) containing various lithological units. The Promina deposits indicate end of emersion and start of sedimentation in changing depositional environments. Deposition of Promina sediments was ended by tectonic movements presumably active from the Lower Oligocene to Pliocene, which largely defined present structural forms [11]. In the deposit pit, calcareous breccia is observed in contact with bauxite, followed by limestone. Such 
a geological setting of deposit was considered most productive in the area assuming the bauxite reserves [12].

The bauxites in the studied area were presumably formed during emersion in the late Mid and Upper Eocene, which followed strong Mid Eocene Illyrian tectonic movements that ended foraminiferal limestone sedimentation [11]. This period coincided with a warm and humid climate that gave rise to extensive weathering and accumulation of derived material on the paleorelief [13]. Local bauxite bodies are usually lens-shaped, sometimes dyke-like, or are pseudo-layered. They are commonly pisolithic, red to brown, mainly of mixed böhmite-gibbsite mineralogy and also including hematite, goethite, anatase, and kaolinite [1]. Earlier studies [14] concluded that formation of bauxite in the area had been heterolithic due to a versatility of material composition, which could have been derived from various rock types in this area. These were on the surface of the paleorelief at the time of bauxite formation (today the footwall rocks of the bauxite deposits), so a larger transport of detrital material was not assumed. The protolithic rocks were various types of Cretaceous and Eocene limestones and Eocene marls. The Eocene marls are not so much widespread in the investigated area nowadays, so it is likely they were strongly weathered during the (sub)tropical climate in Mid/Upper Eocene, and thus, could have significantly contributed to detrital material that ended in bauxite. A possible contribution of Permian and Lower Triassic rocks to the residual material is still to be investigated. 

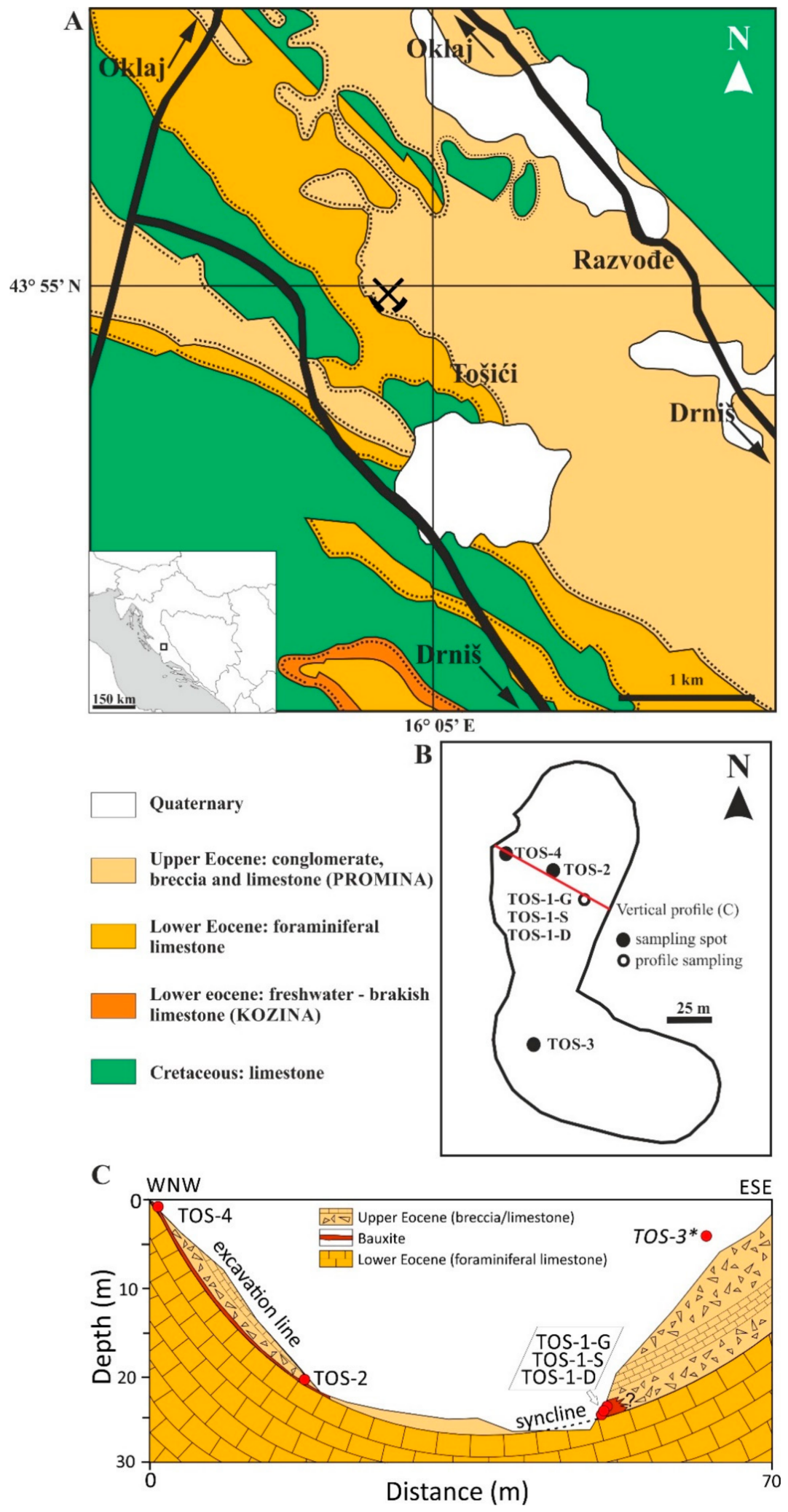

Figure 1. Situation and lithostratigraphic map (after [15]) for the Tošići-Dujići deposit area (the deposit pit is marked with abandoned mine symbol in the map) (A), ground sampling plan (B), and vertical profile outline of exploitation pit along WNW-ESE direction indicating sampling positions ( ${ }^{*}$ TOS-3 was collected at the indicated position situated $80 \mathrm{~m}$ away from the profile towards SSW) (C). 


\section{Materials and Methods}

The bauxite samples were collected at six different positions and depths in the former bauxite exploitation pit within the Tošići-Dujići deposit (Table 1). A complete bauxite profile is not clearly observable, since the majority of the bauxite material was excavated. Thus, it was only possible to collect samples out of remaining bauxite pockets in the ore body. Fortunately, these are available at various depths from the top to the bottom of the open exploitation pit, and are occasionally visible at the sides of the pit. Observations carried out in the deposit excavation pit confirmed Lower Eocene foraminiferal limestone in the footwall for all the samples collected. Hanging wall rocks are missing at all the sampling sites, since they were mostly removed during mining activities. The exemption is a small bauxite pocket sampled in the deepest section of the pit, where Upper Eocene Promina deposits are still present in the hanging wall. Since most of bauxite at the site has been excavated, there are no signs of whether this pocket was connected to the main bauxite body or not, but the excavation situation in the pit suggests that it most likely was. The sampling ground plan is presented in Figure $1 \mathrm{~B}$ and the vertical relationship among sampling sites can be observed in vertical profile outline in Figure 1C. The vertical profile shows that the collected bauxite samples are stratigraphically equivalent. Most of the available sampling sites are situated in the northern part of the exploitation pit. The deepest available bauxite pocket represents a very small profile in the deposit syncline eastern limb, which stretches $23-25 \mathrm{~m}$ in depth in the northeastern part of the pit. This pocket was sampled close to contact to the footwall limestone (TOS-1-D), halfway between the footwall and hanging wall (TOS-1-S), and close to the limestone breccia in the hanging wall (TOS-1-G). The most visible section of the remaining bauxite in the pit is a thin layer $(0.3-0.75 \mathrm{~m})$ between the paleorelief and the just sparsely preserved hanging wall following the western limb of the syncline from the depth of around $20 \mathrm{~m}$ (sample TOS-2) to the top of the pit (sample TOS-4). The sample TOS-3 was collected roughly $80 \mathrm{~m}$ southwards from the rest of the sampling sites, at a depth of $3.5 \mathrm{~m}$, and could represent a remnant of the southern outcrop of the bauxite body that followed the same synclinal form.

For determination of textural properties of the bauxite samples, thin sections were prepared and studied using the polarizing microscope Zeiss Axiolab (Carl Zeiss, Jena, Germany). Bulk mineral composition of the samples was identified by X-ray powder diffractometer Philips PW 3040/60 X'Pert PRO(Philips, Almelo, The Netherlands) using $\mathrm{CuK} \alpha$ radiation (1.54055 $\AA$ ), powered by $40 \mathrm{kV}$ and $40 \mathrm{~mA}$, a graphite monochromator, a primary divergence slit of $\frac{1}{4}$, an antiscatter slit of $\frac{1}{2}$, a receiving slit of $0.2 \mathrm{~mm}$, Soller slits of $0.04 \mathrm{rad}$, and a proportional detector at a recording step of $0.02^{\circ} 2 \theta / \mathrm{s}$ The samples of the two bauxite horizons with the highest REE concentrations were prepared for scanning electron microscopy-energy dispersive spectroscopy (SEM-EDS) analysis in order to study the possible occurrence of REE minerals and their morphological features. Additionally, bauxite matrix was checked by SEM-EDS to confirm XRD findings and to analyze textural features of bauxite. SEM analysis was performed by JEOL JSM-6510 LV (JEOL, Tokyo, Japan) and the Oxford INCA X-act EDS system (Oxford Instruments, High Wycombe, UK).

For chemical analyses, the samples were crushed and pulverized in agate mill and mortar, and sieved repeatedly until complete sample was pulverized down to the sieve size of less than $0.02 \mathrm{~mm}$. All samples were analyzed for major and trace elements using inductively coupled plasma-atomic emission (ICP-AES), and-mass spectrometry (ICP-MS), after being fused with lithium borate and dissolved in nitric acid to obtain total sample decomposition. Additionally, the sample aliquots were also treated by a modified aqua regia digestion $\left(\mathrm{HNO}_{3}: \mathrm{HCl}: \mathrm{H}_{2} \mathrm{O}=1: 1: 1\right)$, and the leachate was analyzed by ICP-AES/MS, so that a fraction of REE in residual mineral phases could be estimated. All chemical analyses were carried out in Bureau Veritas (Acme Analytical Laboratories), Vancouver, BC, Canada. 


\section{Results and Discussion}

\subsection{Textural and Mineralogical Properties}

Thin sections prepared from the bauxite samples collected in the Tošići-Dujići deposits (Figure 2) demonstrate textural differences among the samples, which are described in Table 1.
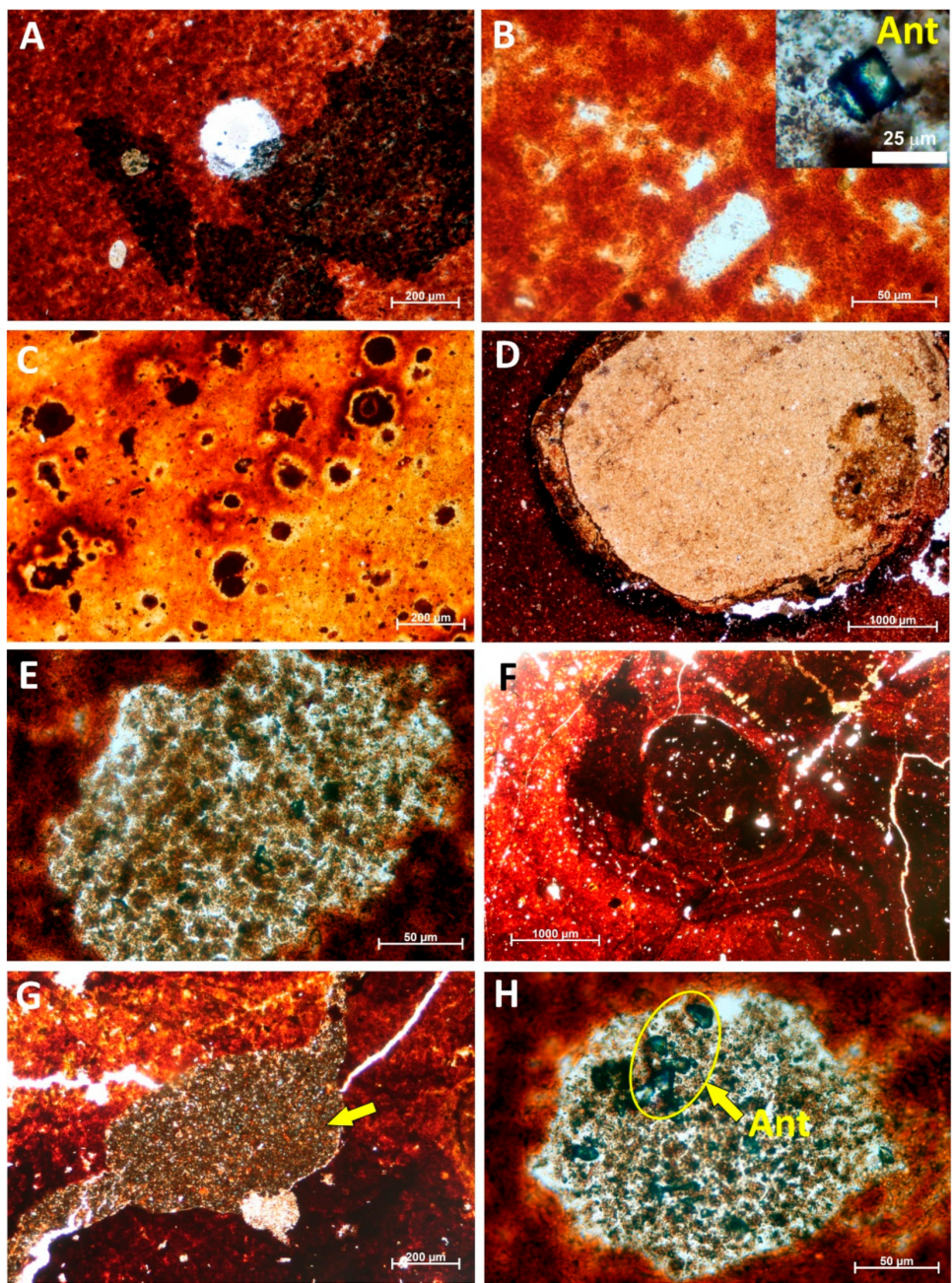

Figure 2. Microphotographs of the Tošići-Dujići bauxite samples: (A)—anhedral to globular gibbsite in pseudoporphyritic structure of TOS-1-D; (B)—anhedral to subhedral gibbsite grains in microgranular texture of TOS-1-S, and euhedral anatase (inset); (C) - panidiomorphic to granular texture with spherical hematite in TOS-1-G; (D) - a pisoid in TOS-2 with gibbsitic core and hematitic rim; (E) — gibbsite grain including hematite and anatase grains in TOS-2; (F)—broken hematitic pisoid in TOS-3 implying redeposition; (G) - a crevice in TOS-3 filled with detrital material (marked by yellow arrow); (H) —nodule-like gibbsite including tiny hematite and anatase grains in TOS-4 (anatase grains in ellipse and pointed out by the arrow).

Mineral composition of bauxite is a useful indicator of parent detrital material and prevailing conditions during bauxitiziation, but it also determines the quality of bauxite for application in industry. XRD analysis yielded gibbsite $\left[\gamma-\mathrm{Al}(\mathrm{OH})_{3}\right]$ and hematite as major phases in all the samples, sometimes accompanied by kaolinite and goethite (samples collected closest to the surface), while böhmite $[\gamma-\mathrm{AlO}(\mathrm{OH})]$, nordstrandite $\left[\mathrm{Al}(\mathrm{OH})_{3}\right]$, and anatase are minor phases (Table 1, Figure 3). With reference to optical microscopy, SEM (Figure 4), and XRD observations, the matrix is mainly composed of hematite, gibbsite, böhmite, kaolinite, illite, goethite, and rutile. 


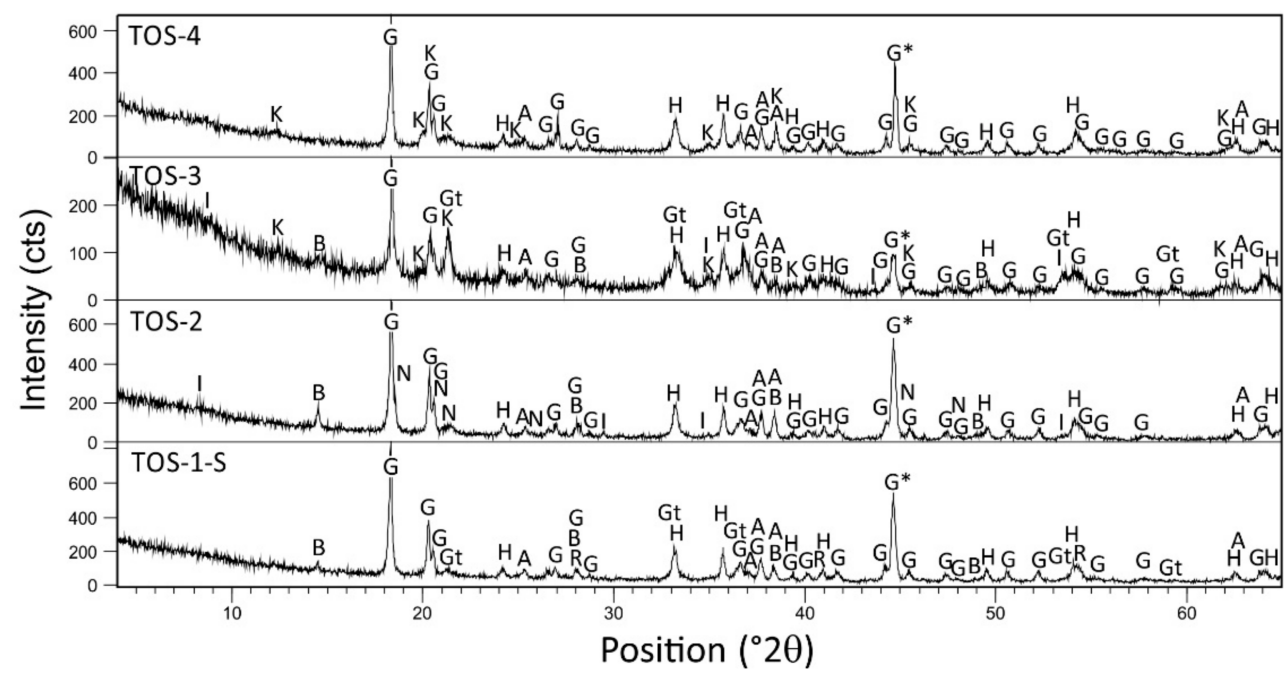

Figure 3. Representative XRD patterns for the samples TOS-1-S, TOS-2, TOS-3, and TOS-4 (G-gibbsite, B-böhmite, N-nordstrandite, H-hematite, Gt-goethite, A-anatase, R-rutile, K-kaolinite, I-illite; * diffraction line of Al-sample holder).

Considering aluminum hydroxide phases, bauxite at the Tošići-Dujići deposit can be classified as mixed gibbsite-böhmite type [1]. Relative intensity of the diffraction maxima in the XRD patterns indicates gibbsite to be more abundant, proving its prevalence in all the samples of the present study. Gibbsite is considered a lateratization product of feldspars and clay minerals [16]. Kaolinite is also present, and it is also a typical weathering product of the tropical weathering of aluminosilicates. A minor amount of böhmite was recorded in all the samples except in the sample collected close to the top of the pit (TOS-4).

Table 1. Textural (after [17]) and mineralogical properties of the bauxite samples investigated in the Tošići-Dujići deposit.

\begin{tabular}{|c|c|c|c|c|}
\hline Sample & Topographic Depth (m) & Texture & Major Phases & Minor Phases \\
\hline TOS-1-D & 25 & $\begin{array}{l}\text { Pseudoporphyritic with anhedral } \\
\text { to globular gibbsite, and hematite } \\
\text { nodules up to } 200 \mu \mathrm{m} \text { in very fine } \\
\text { grained matrix }\end{array}$ & gibbsite, hematite & $\begin{array}{l}\text { böhmite, anatase, } \\
\text { nordstrandite }\end{array}$ \\
\hline TOS-1-S & 24 & $\begin{array}{l}\text { Microgranular with anhedral to } \\
\text { subhedral gibbsite up to } 100 \mu \mathrm{m} \\
\text { in diameter }\end{array}$ & gibbsite, hematite & $\begin{array}{l}\text { goethite, böhmite, } \\
\text { anatase, rutile }\end{array}$ \\
\hline TOS-1-G & 23 & $\begin{array}{l}\text { Panidiomorphic to granular } \\
\text { texture, idiomorphic gibbsite and } \\
\text { sphaerical hematite, all up to } \\
100 \mu \mathrm{m}\end{array}$ & $\begin{array}{c}\text { gibbsite, kaolinite, } \\
\text { hematite }\end{array}$ & anatase, böhmite \\
\hline TOS-2 & 19 & $\begin{array}{l}\text { Pisoidic (gibbsitic in core), also } \\
\text { including anhedral gibbsite } \\
20-100 \mu \mathrm{m} \text { in diameter, hematitic } \\
\text { nodules up to } 150 \mu \mathrm{m}\end{array}$ & gibbsite, hematite & $\begin{array}{l}\text { böhmite, anatase, } \\
\text { nordstrandite, illite }\end{array}$ \\
\hline TOS-3 & 3.5 & $\begin{array}{l}\text { Pisoidic (more hematitic) } \\
\text { with microgranular } \\
\text { (subpanidiomoprhic) to } \\
\text { pseudoporphyritic structure also } \\
\text { including subhedral gibbsite; } \\
\text { secondary filled crevices } \\
\text { implying redeposition }\end{array}$ & $\begin{array}{l}\text { gibbsite, kaolinite, } \\
\text { goethite, hematite }\end{array}$ & anatase, böhmite, illite \\
\hline TOS-4 & 0.5 & $\begin{array}{l}\text { Microgranular, anhedral to } \\
\text { subhedral gibbsite grains up to } \\
50 \mu \mathrm{m} \text { in diameter, also nodules } \\
\text { with tiny hematite and anatase }\end{array}$ & $\begin{array}{c}\text { gibbsite, kaolinite, } \\
\text { hematite }\end{array}$ & anatase \\
\hline
\end{tabular}



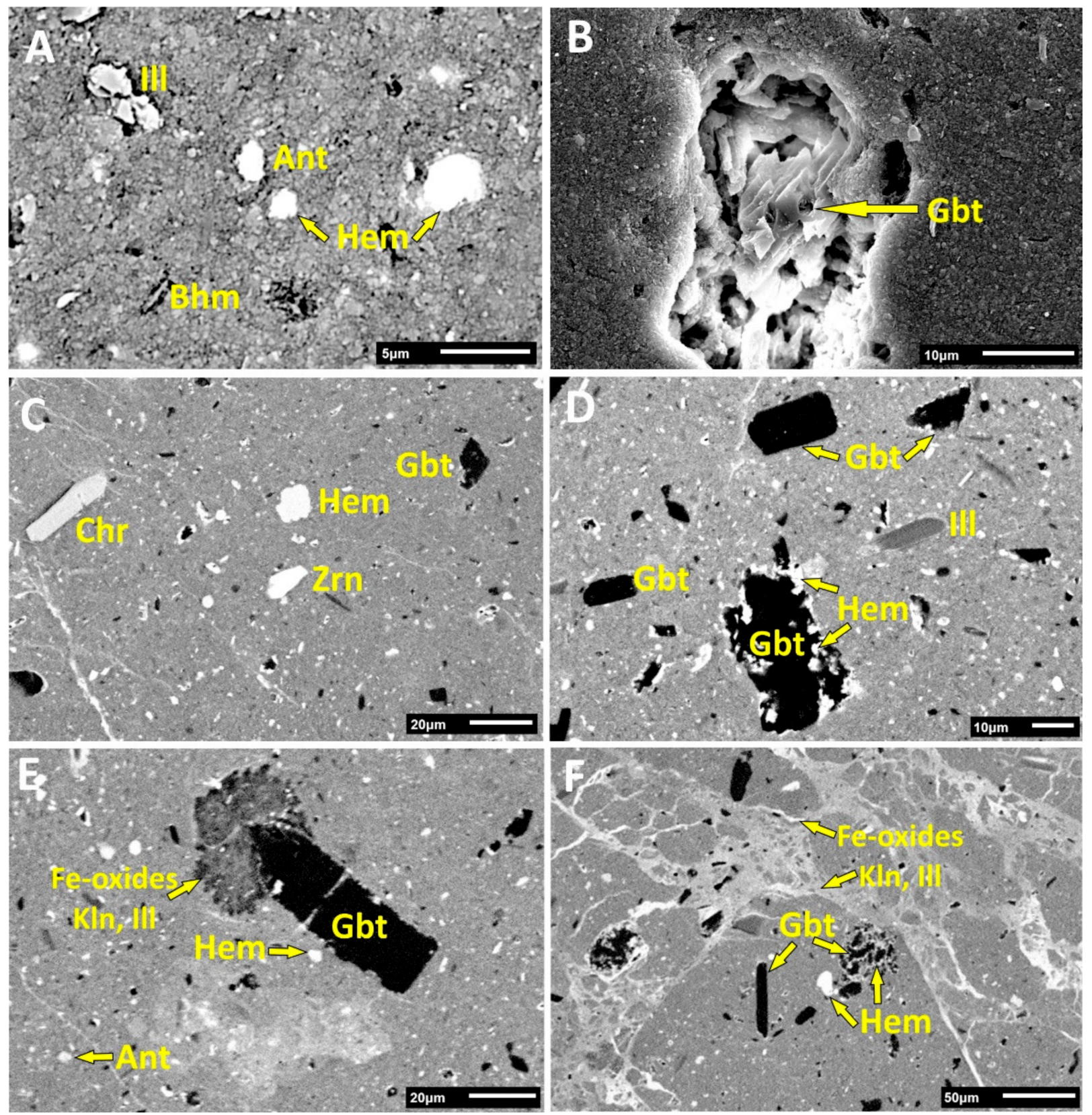

Figure 4. SEM micrographs presenting mineral content (Gbt-gibbsite; Bhm-böhmite; Hem-hematite; Ant-anatase; Zrnzircon; Chr-chromite; Kln-kaolinite; Ill-illite), and textural features of the bauxite matrix: (A)_individual mineral grains of böhmite, hematite, anatase, and illite dispersed in the matrix of sample TOS-2; (B) - gibbsite in a vug of TOS-2 presenting dissolution figures with likely occurrence of finely sprinkled böhmite; (C)-individual mineral grains of gibbsite, hematite, zircon, and chromite dispersed in the matrix of sample TOS-3; (D)-gibbsite grains in TOS-3, which are occasionally covered and intruded with hematite on sites of etching or mechanical abrasion (the largest grain), with the illite grain observed on right; (E) — dispersed individual grains of hematite and anatase, and a large euhedral gibbsite grain in contact with an aggregate of Fe-oxides, kaolinite, and illite in TOS-3; (F) - preserved almost euhedral grains of gibbsite and fragmented gibbsite grains covered and intruded by hematite; veinlets significantly intersecting the sample are filled with Fe-oxides, kaolinite, and illite in TOS-3.

Böhmite is considered to be formed by diagenetic transformation of gibbsite at a temperature range of $35-50{ }^{\circ} \mathrm{C}$ due to water loss $[18,19]$; thus, presumably no extensive transformation of aluminum hydroxides and a smaller extent of diagenetic changes occurred in the deposit. However, in Figure 4A, a tiny elongated böhemite crystal can be observed in the matrix. Dissolution figures on gibbsite with the likely occurrence of small 
böhmite crystals sprinkled on the surface can be spotted in the matrix vugs (Figure 4B). Studies in hydrothermal conditions showed that for the transformation of gibbsite to böhmite, the dissolution-precipitation mechanism is involved, and neoformed böhmite crystals develop crystal morphology depending on $\mathrm{pH}$ [20]. Thus, the elongated böhmite observed in Figure 4A would be favorably crystallized in a more acidic environment, as böhmite recrystallization in alkaline conditions results in an equant or platy habit. The absence of diaspore indicates the absence of metamorphic, hydrothermal, or hypogene processes [21,22].

Minor nordstrandite occurrence was revealed in the bottom sections of the exploitation pit (in TOS-1-D and TOS-2). Nordstrandite was found accompanying gibbsite in bauxite from Jamaica, and its occurrence was related to $\mathrm{SiO}_{2}$ content since it is $\mathrm{pH}$-dependent [23]. In the two nordstrandite-containing samples of the Tošići-Dujići deposit, the $\mathrm{SiO}_{2}$ content was $2.21 \%$ and $2.49 \%$, which corresponds to $1-5 \%$ of the $\mathrm{SiO}_{2}$ found in Jamaican bauxites enriched in nordstrandite. Namely, nordstrandite is formed in slightly alkaline environments maintained by silica content, and it was most likely formed together with gibbsite in an early stage of bauxite formation,

Hematite is ubiquitous in all investigated samples, irrespective of their position in the bauxite profile. SEM images reveal various appearances of hematite: single subhedral grains, incrustations around gibbsite, and as filling material in veinlets with clay phases (kaolinite and illite) (Figure 4). This suggests various origins of hematite in the deposit: some of it was most likely formed during bauxitiziation, some was detrital, and some indicates reworking of material, particularly in the upper section of the deposit. Occasional minor goethite occurrence along with hematite could reflect gradual goethite-hematite transformation due to dehydration, while goethite could be an oxidation product of Febearing minerals that originated from the detrital material.

$\mathrm{TiO}_{2}$ is by far represented by anatase, usually formed syngenetically with bauxite [17], but detrital origin cannot be excluded. Here, it is present as generally tiny (usually up to $10 \mu \mathrm{m}$ ) subhedral grains dispersed throughout the matrix of all the samples (Figure 4A), but sometimes the grains are more concentrated, forming nodular nests (Figure 2E,H), which could be due to reworking and redeposition as inferred from the subangular appearance of some grains [24]. Some grains could be considered authigenic, since they are larger in size and euhedral with overgrowing (Figure 2B, inset). Prevalence of anatase among $\mathrm{TiO}_{2}$ mineral phases suggests more reducing conditions during the formation of bauxite deposits in karst terrains [25]; however, in Tošići-Dujići, it is likely that both authigenic and detrital anatase are present. Rutile, on the other hand, was spotted just in TOS-1-D.

The occurrence of minerals like hematite and goethite, which strongly favor oxidizing conditions, and anatase, with more reducing preference, could suggest various origins of anatase grains, but also suggest a change of Eh conditions in the deposits during bauxitization and the diagenetic processes, which can be also related to a likely change of the water table in karstic depressions accommodating the bauxite bodies in the area. This is further supported by the change in Ce anomaly, as well as by the La/Y ratio change (Figure 5), which suggests variable $\mathrm{pH}$ conditions in different deposit sections with $\mathrm{La} / \mathrm{Y}<1$ indicating acidic conditions [25-27]. 


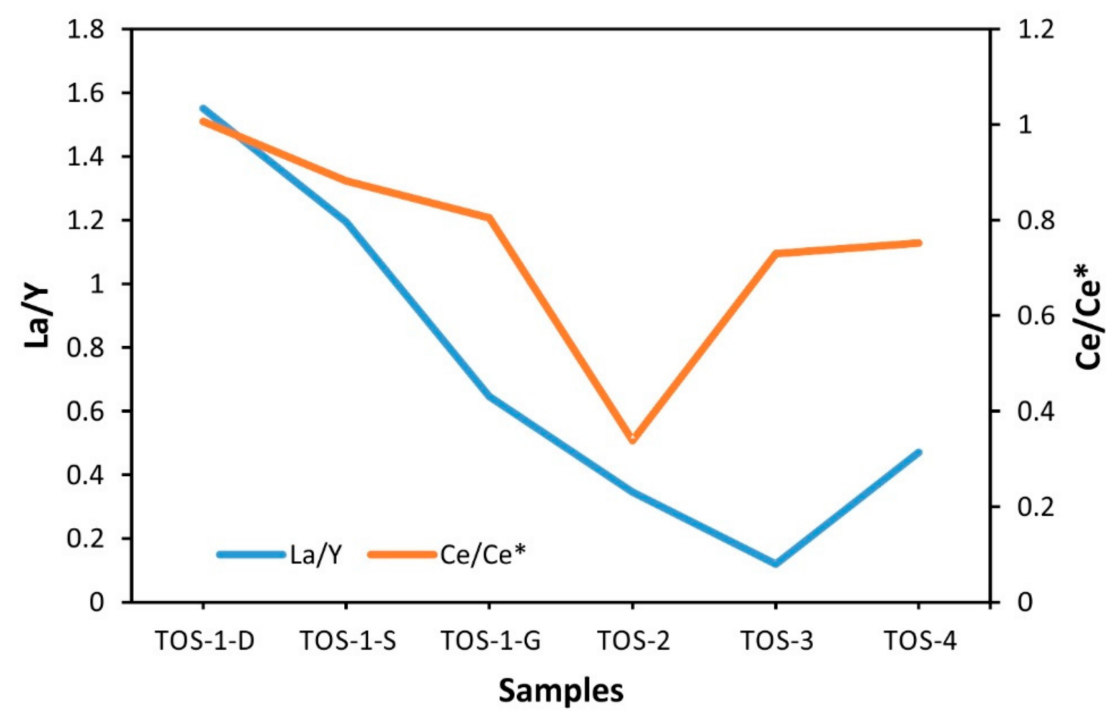

Figure 5. La/Y ratio and Ce anomaly variability expressed as $\mathrm{Ce} / \mathrm{Ce}{ }^{*}$ in the bauxite samples of the Tošići-Dujići deposit.

\subsection{Geochemical Signature}

Major constituents and REE abundances in the bauxite samples from the Tošići-Dujići deposit are presented in Table $2 . \mathrm{SiO}_{2}$ is inhomogeneously distributed through the deposit ranging from $2.21-14.2 \%$.

Table 2. Chemical composition of the bauxite samples from Tošići-Dujići (major components in wto; Ni, Sc, REE in mg/kg) together with REE fractionation values $\left(\mathrm{Ce} / \mathrm{Ce}^{*}, \mathrm{Eu} / \mathrm{Eu}^{*}\right.$, and $\left.\mathrm{La} / \mathrm{Yb}\right)$.

\begin{tabular}{|c|c|c|c|c|c|c|}
\hline $\begin{array}{l}\text { Major/Trace } \\
\text { Component }\end{array}$ & TOS-1-D & TOS-1-S & TOS-1-G & TOS-2 & TOS-3 & TOS-4 \\
\hline & \multicolumn{6}{|c|}{ Major components (wt\%) } \\
\hline $\mathrm{SiO}_{2}$ & 2.21 & 4.14 & 8.98 & 2.49 & 6.78 & 14.2 \\
\hline $\mathrm{Al}_{2} \mathrm{O}_{3}$ & 47.12 & 46.43 & 47.34 & 46.82 & 33.79 & 41.05 \\
\hline $\mathrm{Fe}_{2} \mathrm{O}_{3}$ & 19.05 & 19.65 & 12.57 & 19.97 & 35.08 & 17.83 \\
\hline $\mathrm{MgO}$ & 0.12 & 0.13 & 0.2 & 0.12 & 0.15 & 0.32 \\
\hline $\mathrm{CaO}$ & 0.32 & 0.33 & 0.46 & 0.95 & 0.28 & 0.37 \\
\hline $\mathrm{Na}_{2} \mathrm{O}$ & 0.02 & 0.02 & 0.02 & 0.02 & 0.04 & 0.04 \\
\hline $\mathrm{K}_{2} \mathrm{O}$ & 0.01 & 0.03 & 0.08 & 0.05 & 0.32 & 0.16 \\
\hline $\mathrm{TiO}_{2}$ & 2.3 & 2.22 & 2.38 & 2.1 & 1.54 & 2.05 \\
\hline $\mathrm{P}_{2} \mathrm{O}_{5}$ & 0.20 & 0.22 & 0.25 & 0.39 & 0.42 & 0.15 \\
\hline $\mathrm{MnO}$ & 0.9 & 0.3 & 0.72 & 0.12 & 0.09 & 0.12 \\
\hline $\mathrm{Cr}_{2} \mathrm{O}_{3}$ & 0.112 & 0.125 & 0.153 & 0.133 & 0.092 & 0.165 \\
\hline $\mathrm{Ni}$ & 397 & 393 & 704 & 479 & 564 & 554 \\
\hline Sc & 67 & 69 & 55 & 75 & 67 & 61 \\
\hline LOI & 27 & 25.8 & 26.1 & 25.9 & 20.6 & 22.9 \\
\hline \multirow[t]{2}{*}{ Total } & 99.44 & 99.42 & 99.32 & 99.1 & 99.2 & 99.45 \\
\hline & \multicolumn{6}{|c|}{ Rare earth elements $(\mathrm{mg} / \mathrm{kg})$} \\
\hline Y & 127.3 & 179.1 & 353.9 & 1346.1 & 1328 & 408.1 \\
\hline $\mathrm{La}$ & 197.4 & 214 & 228.7 & 465.2 & 158.5 & 191.7 \\
\hline $\mathrm{Ce}$ & 364.4 & 361.4 & 368.5 & 347.8 & 253.4 & 283.4 \\
\hline $\operatorname{Pr}$ & 32.98 & 38.94 & 45.57 & 113.06 & 37.81 & 36.84 \\
\hline $\mathrm{Nd}$ & 118 & 144.3 & 203.3 & 523.6 & 199.3 & 148.9 \\
\hline $\mathrm{Sm}$ & 24.13 & 27.75 & 49.54 & 109.69 & 59.83 & 37.25 \\
\hline $\mathrm{Eu}$ & 5.51 & 6.67 & 11.85 & 29.42 & 15.69 & 9.61 \\
\hline $\mathrm{Gd}$ & 22.73 & 28.7 & 55.66 & 182.12 & 82.03 & 48.79 \\
\hline $\mathrm{Tb}$ & 3.88 & 4.67 & 7.99 & 24.92 & 11.6 & 7.86 \\
\hline Dy & 23.61 & 29.5 & 46.27 & 149.25 & 70.48 & 49.31 \\
\hline
\end{tabular}


Table 2. Cont.

\begin{tabular}{|c|c|c|c|c|c|c|}
\hline $\begin{array}{l}\text { Major/Trace } \\
\text { Component }\end{array}$ & TOS-1-D & TOS-1-S & TOS-1-G & TOS-2 & TOS-3 & TOS-4 \\
\hline Ho & 4.95 & 6.07 & 9.87 & 35.82 & 17.08 & 10.98 \\
\hline $\mathrm{Er}$ & 15.12 & 18.33 & 28.2 & 95.43 & 52.9 & 32.17 \\
\hline $\mathrm{Tm}$ & 2.27 & 2.67 & 3.73 & 10.7 & 6.8 & 4.41 \\
\hline $\mathrm{Yb}$ & 14.64 & 17.51 & 22.74 & 54.64 & 38.69 & 26.43 \\
\hline $\mathrm{Lu}$ & 2.25 & 2.62 & 3.38 & 8.1 & 6.15 & 4 \\
\hline LREE & 742.42 & 793.06 & 907.46 & 1588.77 & 724.53 & 707.7 \\
\hline HREE & 216.75 & 289.17 & 531.74 & 1907.08 & 1613.73 & 592.05 \\
\hline Total REE & 959.17 & 1082.23 & 1439.2 & 3495.85 & 2338.26 & 1299.75 \\
\hline $\mathrm{Ce} / \mathrm{Ce}^{*}$ & 1.01 & 0.88 & 0.80 & 0.34 & 0.73 & 0.75 \\
\hline $\mathrm{Eu} / \mathrm{Eu}^{*}$ & 0.72 & 0.73 & 0.70 & 0.64 & 0.69 & 0.70 \\
\hline $\mathrm{La} / \mathrm{Yb}$ & 8.72 & 7.91 & 6.51 & 5.51 & 2.65 & 4.69 \\
\hline
\end{tabular}

This assumes the fluctuating intensity of chemical weathering and the corresponding change of conditions through the bauxite deposits, such as $\mathrm{pH}$ that presents lower values in deeper deposit pit sections, which can be inferred from La/Y ratio (Figure 5). The content of $\mathrm{Al}_{2} \mathrm{O}_{3}$ exceeds $45 \%$ in topographically lower parts of the deposit (all TOS-1 samples and TOS-2), and the $\mathrm{Al}_{2} \mathrm{O}_{3}: \mathrm{SiO}_{2}$ ratio is generally $>4$ in all but TOS-4. There is an evident pattern of $\mathrm{Al}_{2} \mathrm{O}_{3}$ increase and concomitant $\mathrm{SiO}_{2}$ decrease, which suggests chemical weathering to be much more pronounced in some parts of the deposit However, as suggested by redeposition and possible influx of the detrital material, $\mathrm{SiO}_{2}$ content could have been increased by depositional processes, particularly due to observable clay content (Figure 4D-F).

$\mathrm{TiO}_{2}$ is slightly above $2 \%$ in all samples except in TOS-3. It is mostly represented by anatase, and minor variations in its content could just indicate fine changes in detrital source and/or slightly varying bauxitization degree. However, the $\mathrm{TiO}_{2}$ decrease in TOS-3 could be due to redeposition or influx of detrital material from other sources. Indeed, a broken hematitic pisoid and a crevice filled with detrital material can be observed in Figure 2F,G, respectively, both indicating reworking and redeposition. In Figure $4 C, D$, detrital minerals like zircon, illite, and elongated chromite, which is characteristic for metamophized ophiolites [28], provide evidence of the allochtonous contribution of detrital material.

$\mathrm{Fe}_{2} \mathrm{O}_{3}$ content is quite variable: from $12.57 \%$ in the upper part of the small profile at the bottom of the exploitation pit (TOS-1-G) to up to $35.08 \%$ in TOS-3. Again, TOS-3 significantly differs from other samples, showing possible reworking of detrital material and/or contribution from various sources, which could have led to the accumulation of iron species. Besides the previously noted textural features in Figure 2, which suggest reworking of the material, Figure $4 \mathrm{D}-\mathrm{F}$ evidence various occurrences of hematite and likely goethite, which could have been affected by redeposition. Figure 4D,F present gibbsite grains either being eroded and etched at the rims, or being completely fragmented, implying reworking of the material, which was subsequently coated with hematite. Along with this, the sample is cut with many veinlets filled with clay minerals (illite and kaolinite) and Fe-oxide component. XRD data show both hematite and goethite are present in this highly Fe-enriched sample. This can implicate various origins of hematite, but also variable $\mathrm{pH}$ conditions, as crystallization of hematite is favored at more neutral $\mathrm{pH}$ while goethite can be formed in both acidic ( $\mathrm{pH} 2-5)$ and alkaline solutions ( $\mathrm{pH} 10-14)$, and prevalence of hematite can point to higher temperatures [29]. The La/Y ratio suggests more acidic conditions in this case.

The ternary diagram $\mathrm{SiO}_{2}-\mathrm{Al}_{2} \mathrm{O}_{3}-\mathrm{Fe}_{2} \mathrm{O}_{3}$ (after [30]) (Figure 6A) shows that the samples are mostly ferritic bauxite with the exemption of TOS-1-G and TOS-4, which belong to the bauxite field. In both cases, strong lateritization can be assumed, which is confirmed by the diagram after [31] presented in Figure 6B. 

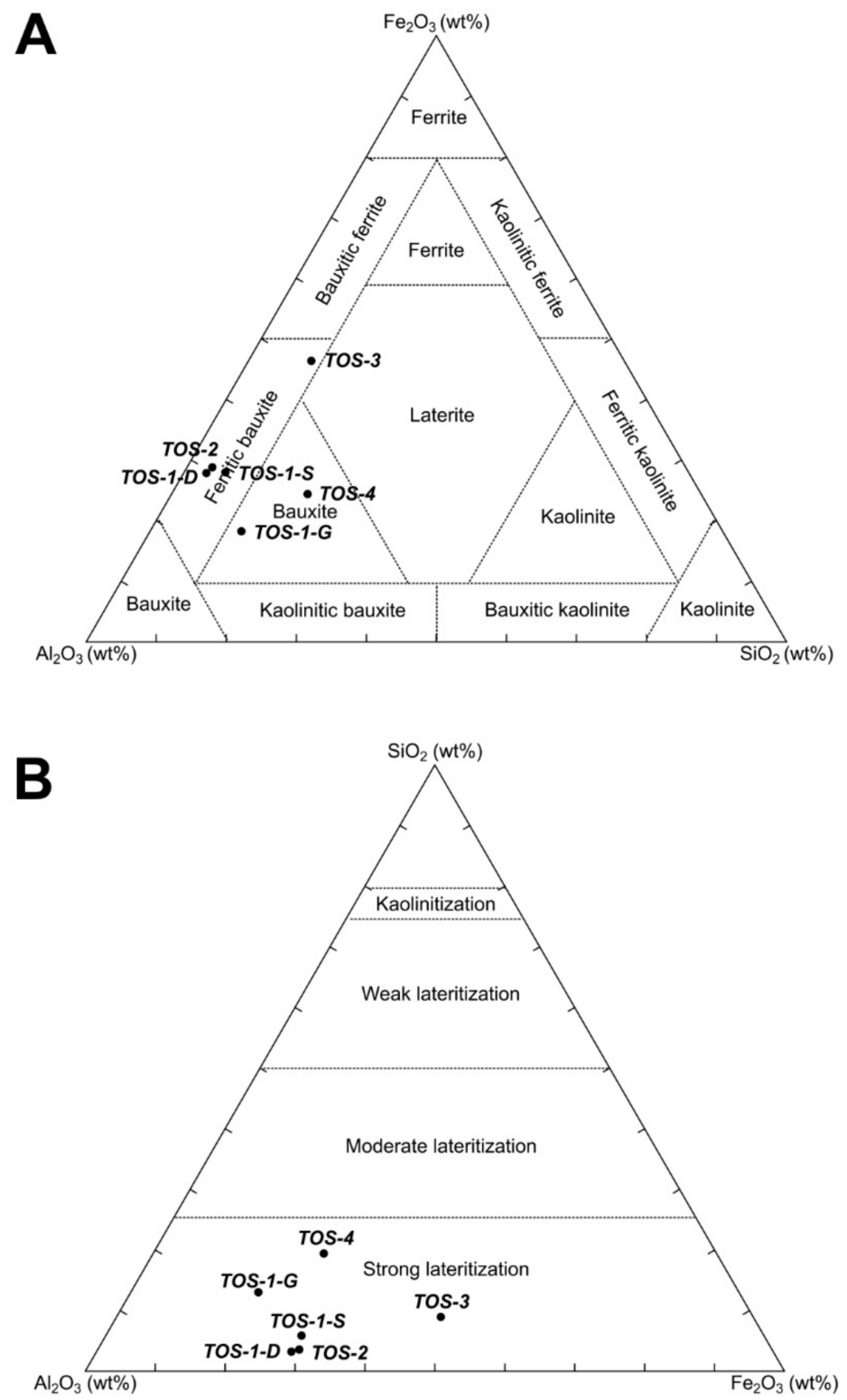

Figure 6. Ternary diagrams: (A) $-\mathrm{SiO}_{2}-\mathrm{Al}_{2} \mathrm{O}_{3}-\mathrm{Fe}_{2} \mathrm{O}_{3}$ after [30] presenting mineralogical classification of bauxite in the Tošići-Dujići deposit; (B) $-\mathrm{Al}_{2} \mathrm{O}_{3}-\mathrm{SiO}_{2}-\mathrm{Fe}_{2} \mathrm{O}_{3}$ after [31] showing degree of lateritization in the Tošići-Dujići deposit.

\subsubsection{REE Distribution}

Total REE abundances in the analyzed samples range from 959 to $3496 \mathrm{mg} / \mathrm{kg}$ (Table 2). The samples of TOS-2 with almost $3500 \mathrm{mg} / \mathrm{kg}$ and of TOS-3 reaching slightly over $2300 \mathrm{mg} / \mathrm{kg}$ of REE are especially interesting. Except TOS-1-D, all samples exceed $1000 \mathrm{mg} / \mathrm{kg}$, which can trigger REE mineralization, as shown in the case of many other Mediterranean bauxite deposits [4]. Another interesting feature is the LREE/HREE ratio ranging from roughly 3.5 to 0.4 . The samples with the highest REE abundances also show the lowest LREE/HREE ratio, making them enriched in HREE. HREE enrichment is largely on account of high yttrium abundances. How total REE abundances in the Tošići-Dujići deposit compare to those in some selected karst bauxite deposits of the Mediterranean area is shown in Table 3. Like the Tošići-Dujići deposit, the numbers for other deposits also show uneven distribution of total REE abundances in the deposits and within the same bauxite formations, like in the Abruzzi region [32]. Total REE abundances in the selected deposits are generally lower than in the Tošići-Dujići deposit; however, taking inhomogeneous 
REE distribution into account, it is likely that such REE abundances can be found in other deposits too. Indeed, some extreme REE abundances have been reported, for instance in Montenegro and Hungary, and those were ascribed to REE concentration with depth by bauxitiziation or accumulation of REE detrital minerals $[7,26]$. As can be observed, in the bauxite deposits, LREE generally dominate over HREE; however, in some horizons of Tošići-Dujići, this LREE prevalence is minor, mostly due to a significant $Y$ content.

$\mathrm{La} / \mathrm{Y}$ ratios indicate mostly acid conditions during bauxitization except for the samples TOS-1-D and TOS-1-S (Figure 5), which seem to be bauxitized in a slightly alkaline environment $(\mathrm{La} / \mathrm{Y}>1)$. Some microtextural properties observed in Figures 2 and 4 evidence reworking of the material as well as its heterolithic origin, which might have contributed to the change of $\mathrm{pH}$ conditions. In acidic conditions, REE can be mobilized and transported towards lower portions of bauxite profile, where they can be retained in carbonate mineral phases once neutral or alkaline conditions prevail, which are controlled by the alkaline barrier close to the footwall limestones [3,33]. However, although some samples are significantly enriched in REE, prevailing acidic conditions were not favorable for formation of common fluorocarbonate phases like bastnäsite-(Ce) or parisite-(Ce) in the bauxite profile.

Table 3. Comparison of REE abundances in the Tošići-Dujići deposit with REE content in selected karst bauxite deposits of the Mediterranean area (data for Montenegro bauxites from [34], for Abruzzi bauxites in Italy from [32], and for Parnassos-Giona bauxites in Greece from [3,4]) (Ln = lanthanides).

\begin{tabular}{|c|c|c|c|c|c|c|}
\hline $\begin{array}{c}\text { Bauxite } \\
\text { Age/REE } \\
\text { Subdivision } \\
\text { Totals }\end{array}$ & $\begin{array}{c}\text { Vojnik- } \\
\text { Maganik } \\
\text { Bauxite Region } \\
\text { (Montenegro)* }\end{array}$ & $\begin{array}{c}\text { Vojnik- } \\
\text { Maganik \& } \\
\text { Prekornica } \\
\text { Bauxite Region } \\
\text { (Montenegro) * }\end{array}$ & $\begin{array}{c}\text { Parnassos- } \\
\text { Giona } \\
\text { (Greece) }\end{array}$ & $\begin{array}{c}\text { Vecchia Miniera } \\
\text { Abruzzi (Italy) }\end{array}$ & $\begin{array}{l}\text { Campo Felice, } \\
\text { Abruzzi (Italy) }\end{array}$ & $\begin{array}{l}\text { Tošići-Dujići } \\
\text { (Croatia) }\end{array}$ \\
\hline $\begin{array}{c}\text { Bauxite/ } \\
\text { paleorelief Age }\end{array}$ & Late Triassic & Early Jurassic & $\begin{array}{c}\text { Late } \\
\text { Jurassic-Middle } \\
\text { Cretaceous }\end{array}$ & $\begin{array}{l}\text { Early/Late } \\
\text { Cretaceous }\end{array}$ & $\begin{array}{l}\text { Early/Late } \\
\text { Cretaceous }\end{array}$ & Late Eocene \\
\hline $\mathrm{Y}$ & 128 & 128 & $44-159$ & $72-93$ & 83-105 & $127-1346$ \\
\hline Total Ln & 840 & 929 & $343-1122$ & $631-912$ & $592-933$ & $832-2150$ \\
\hline LREE & 755 & 841 & $317-948$ & $567-664$ & $526-854$ & 724-1589 \\
\hline HREE & 213 & 216 & $71-333$ & $134-160$ & $152-183$ & 217-1907 \\
\hline Total REE & 968 & 1057 & $387-1282$ & $718-984$ & 689-1038 & $959-3496$ \\
\hline LREE/HREE & 3.5 & 3.9 & $2.8-4.5$ & $3.7-6.3$ & $3.2-4.7$ & $0.4-3.4$ \\
\hline
\end{tabular}

Fractionation between LREE and HREE, which is expressed as $\mathrm{La}_{\mathrm{ch}} / \mathrm{Yb}_{\mathrm{ch}}$, achieves values close to those for the upper continental crust $(8.82$; calculated using data from [35,36]) (Table 2) only in some parts of the deposit at the locality, suggesting a change in fractionation trend during bauxitization. As previously shown, some lower sections of the deposit recorded alkaline conditions during bauxitization, which possibly prevented REE mobility, particularly of HREE. However, other parts of the bauxite profile show significantly lower values of LREE/HREE ratio, being the lowest in TOS-3 due to a significant increase of HREE. This increase could be also related to a parent material composition as well as to its physical and chemical transformation as shown later.

In general, REE enrichment in bauxite has been previously ascribed to: (a) REE substitution in Al-bearing minerals like gibbsite and böhmite due to complex replacement mechanisms; (b) REE adsorption on clay minerals and Fe-oxyhydroxides; (c) occurrence of REE-bearing detrital minerals (zircon, monazite, xenotime); and (d) neoformation of REE authigenic minerals [25] (and references therein). A correlation of REE to other major and minor elements, demonstrating possible REE affinity to mineral phases in bauxite, could be useful in an assessment of the mechanisms responsible for REE distribution in a bauxite profile. However, a small number of the total samples in this case study have to be considered when evaluating the correlation results. In the Tošići-Dujići deposit, LREE show a strong positive correlation to $\mathrm{CaO}(0.99)$ with the exception of $\mathrm{Ce}$. Ce is strongly correlated with $\mathrm{Al}_{2} \mathrm{O}_{3}(0.96)$ and $\mathrm{TiO}_{2}(0.91)$. This can be associated with adsorption of $\mathrm{Ce}^{4+}$ 
to kaolinite forming monomeric and polymeric hydroxyl cations [37], but also to interstitial solid solubility into anatase [38], respectively. On the other hand, $\mathrm{Ce}-\mathrm{SiO}_{2}$ correlation is negative (-0.51); thus, $\mathrm{Ce}^{4+}$ could have been preferably fractioned due to adsorption to Al-hydroxide mineral phases [39] rather than onto kaolinite.

This cerium behavior in weathering as well as in bauxitization profile is ruled by $\mathrm{Ce}^{3+} \rightarrow \mathrm{Ce}^{4+}$ oxidation, which can divert $\mathrm{Ce}$ from other REE in the profile. Indeed, the analytical data show that $\mathrm{Ce}$ is more abundant in the samples collected closer to hanging wall carbonates. This pattern in $\mathrm{Ce}$ abundances also corresponds to $\mathrm{pH}$ conditions indicated by the La/Y ratio. Thus, Ce abundances are poorly correlated to the rest of REE, implying Ce separation from other REE in the bauxite deposit due to its oxidation. Additionally, $\mathrm{U}$ and Th show a high positive correlation to Ce (0.93 and 0.92), which no other REE does, so occurrence of cerianite $\left[\left(\mathrm{Ce}^{4+}, \mathrm{Th}\right) \mathrm{O}_{2}\right]$ might be assumed. Such a Ce behavior could reduce the magnitude of LREE correlation to phosphorous (0.52), which, on the other hand, could be expected due to the observed phosphate LREE minerals in parts of the bauxite profile of the Tošići-Dujići deposit (see later discussion on REE mineralogy). HREE are strongly correlated to $\mathrm{P}(0.90)$, thus implying HREE attachment to phosphates.

The leaching experiment employing a modified aqua regia dissolution method (Figure 7) showed that $32-58 \%$ of REE are extracted from the samples (thereof, LREE 34-64\%, HREE 44-67\%). Again, LREE are strongly correlated to Ca (0.90), while HREE are positively correlated with P (0.87) in the leachate. Considering mineral solubility, LREE are likely to be associated with carbonates, and HREE with phosphates, which are expectedly just partly attacked by the acids due to their limited solubility [40].

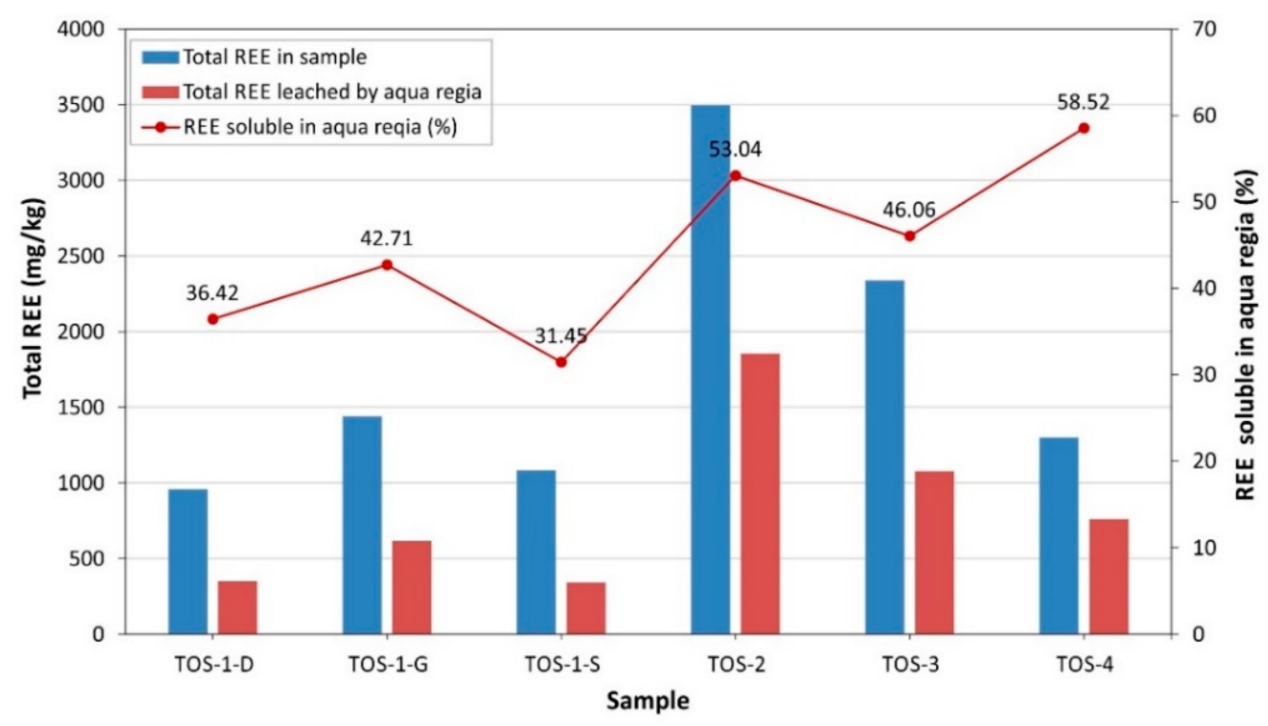

Figure 7. Total REE content leached out of the bauxite samples by a modified aqua regia digestion compared to total REE content in the samples. 
4.2.2. REE Fractionation, Implications to Origin of Parent Material, and Its Fate during Bauxitization

Normalized REE patterns (Figure 8) can be quite interesting when observed using different normalization reference materials: chondrite normalization shows REE distribution and enrichment more inherent to bauxite parent material, bulk crust normalization features a signature of REE enrichment partly inherited from parent material but also due to bauxitization, and finally, upper crust and NASC normalization could further decipher bauxitization contribution to REE distribution in a bauxite profile.
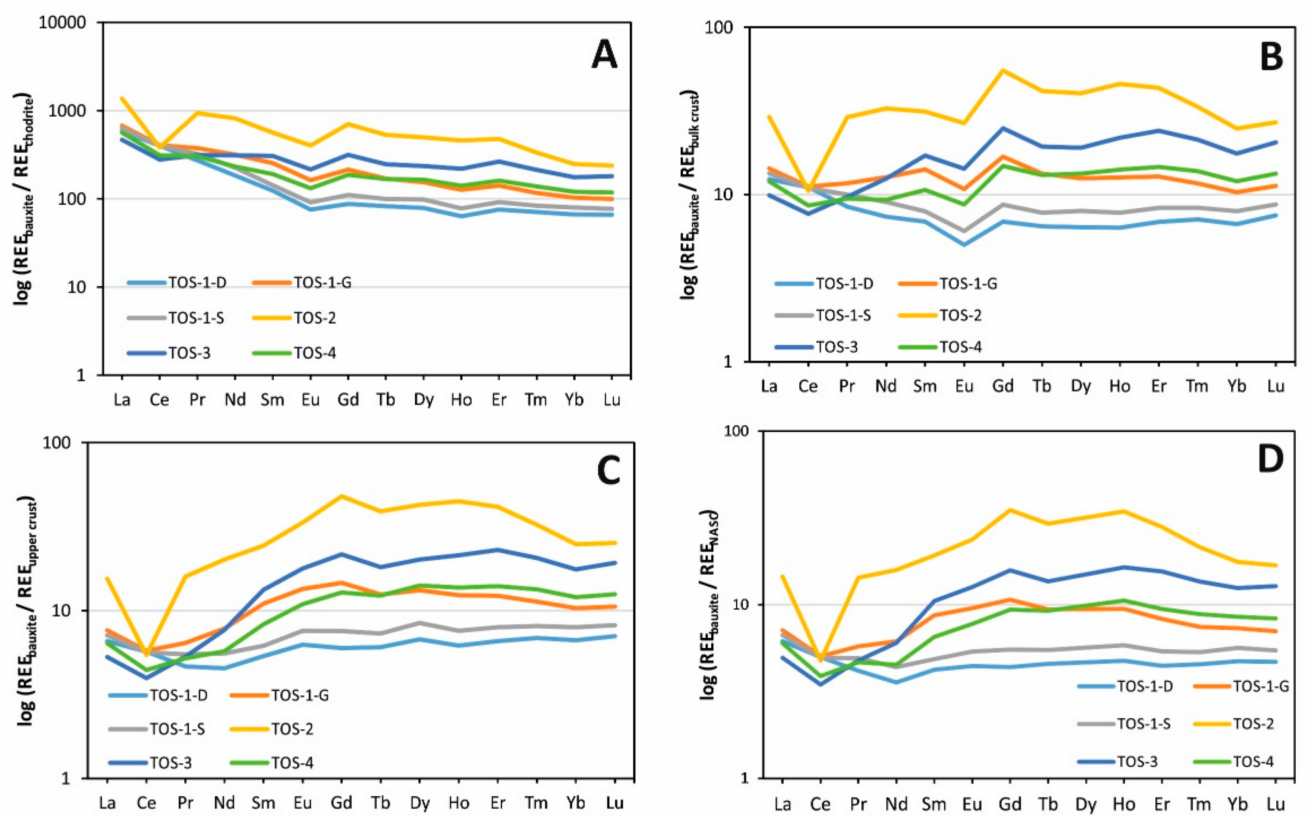

Figure 8. REE distribution in the samples of the Tošići-Dujići deposit: (A) Chondrite normalized REE patterns (chondrite data from [36]); (B) Bulk continental crust normalized REE patterns (bulk continental crust data from [35]); (C) Upper-crust normalized REE patterns (upper crust data from [35]); (D) NASC normalized REE patterns (NASC data from [41]; value for Dy is interpolated due to missing data in the NASC dataset).

Chondrite normalized patterns (Figure 8A) show rather flat REE distribution with slight LREE enrichment and Eu negative anomaly in the samples, suggesting that bauxite parent material was differentiated from primitive mantle composition. The samples with the highest REE abundances show negative Ce anomaly, probably accounting for Ce removal in the upper parts of the bauxite deposit due to Ce oxidation to $\mathrm{Ce}^{4+}$. Generally, REE enrichment relative to chondrite composition ranges from around hundred (HREE) up to almost thousand times in the case of some LREE.

Bulk crust normalized REE patterns (Figure 8B) are generally flatter than those normalized to chondrite. However, for majority of the most REE enriched samples (TOS-2, TOS-3, TOS-4), HREE enrichment is observed. Relative enrichment is around factor 10, but reaches 20-30 or over in the case of HREE for two samples (TOS-2 and TOS-3), and TOS-2 is the most enriched. Eu depletion is still present, leaving a strong imprint of parent material REE distribution. Ce depletion is still present too, pointing to a systematic Ce oxidation and removal from most bauxite sections.

Upper crust normalization (Figure 8C) for all the samples presents patterns with observable HREE enrichment, being particularly expressed in the most REE abundant bauxite samples. Eu depletion is not present anymore, showing relative Eu enrichment during bauxitization, which was strong enough to annihilate the inherent negative Eu anomaly. This could be due to $\mathrm{Eu}^{2+}$ oxidation and significant input of detrital material, which was additionally reworked as suggested by textural properties. 
NASC normalized patterns (Figure 8D) generally follow the upper crust normalized patterns, with just slightly less pronounced enrichment relative to normalization dataset.

$\mathrm{Ce}$ anomaly values $\left(\mathrm{Ce} / \mathrm{Ce}^{*}\right.$, where $\mathrm{Ce}^{*}=(\mathrm{La} \times \mathrm{Pr})^{1 / 2}$; chondrite normalized abundances are used for calculation) change more substantially ranging 0.34-1.01 (Table 2, Figure 5). The least negative Ce anomaly (0.80-1.01) is recorded in the small profile section at the bottom of the deposit pit, with TOS-1-D achieving even slightly positive value. The value of $\mathrm{La} / \mathrm{Y}$ for this sample predicts alkaline conditions, which could sustain formation of stable $\mathrm{Ce}^{4+}$ phases like cerianite [8] and thus support positive Ce anomaly; however, these phases have not been confirmed in these samples. The largest negative anomaly (0.34) is observed in TOS-2, with La/Y values typical for acidic environment that favors removal of cerium (Figure 3).

$\mathrm{Eu}$ anomaly, expressed as ratio $\mathrm{Eu} / \mathrm{Eu}^{*}$ for chondrite normalized abundances (where $\left.\mathrm{Eu}^{*}=(\mathrm{Sm} \times \mathrm{Gd})^{1 / 2}\right)$, usually retains its values similar to those of parent rock during weathering and bauxitization [42,43], and is also used as an index of chemical differentiation. The values of Eu anomaly in the Tošići-Dujići bauxite samples range from 0.64-0.73 (Table 2), and are generally consistent implying same or similar source of detrital material, and indicate that bauxitization did not influence them largely. The negative anomaly attains maximal values in the sample with the highest REE content (TOS-2), probably retaining the most of the protolith REE imprint. As previously described, the Eu depletion is diminishing as crustal reference materials are used, proving REE enrichment due to preferential enrichment.

$\mathrm{Eu} / \mathrm{Eu}^{*}$ values can also be related to other geochemical features in order to devise the possible source of material for a bauxite deposit. After establishing strong correlation between $\mathrm{TiO}_{2}$ and $\mathrm{Al}_{2} \mathrm{O}_{3}$ in a binary plot (Figure $9 \mathrm{~A}$ ), which suggests Ti immobility during chemical weathering [44], the $\operatorname{LogNi} / \log C r$ binary diagram after [45] confirms all studied bauxite samples fall in the field of karstic bauxite (Figure $9 \mathrm{~B}$ ). The $\mathrm{TiO}_{2} / \mathrm{Al}_{2} \mathrm{O}_{3}$ ratio can be related to the $\mathrm{Eu} / \mathrm{Eu}^{*}$ ratio, in order to obtain a more complex indication of provenance of detrital material (Figure 9C). The Tošići-Dujići bauxite samples plot closest to upper continental crust values (UCC), thus making overall geochemical signature much closer to sedimentary origin of the detrital material. This is further supported by the $\mathrm{Eu} / \mathrm{Eu}^{*}$ and $\mathrm{Sm} / \mathrm{Nd}$ binary plot (Figure 9D), which indicates strongest affiliation of the bauxite samples to UCC but also both to North American Shale Composite (NASC) and PostArchean Australian Shale (PAAS) as well as to cratonic sandstones, especially when Eu/Eu* values are concerned. Additionally, $\mathrm{Eu} / \mathrm{Eu}^{*}$ value plots the bedrock limestone in the diagram similarly. However, $\mathrm{Sm} / \mathrm{Nd}$ values show greater spread among the samples and bedrock limestone, likely implying heterolitic origin of detrital material and allochtonous material influx. The possibly contributing lithology of the investigated area along with already described Lower Eocene limestones, also includes marl deposits as well as a bit more distal Permian sediments [11]. All these lithologies could have contributed to the detrital material for bauxite formation as well as to aluminosilicate residual fraction of the bedrock limestone. 

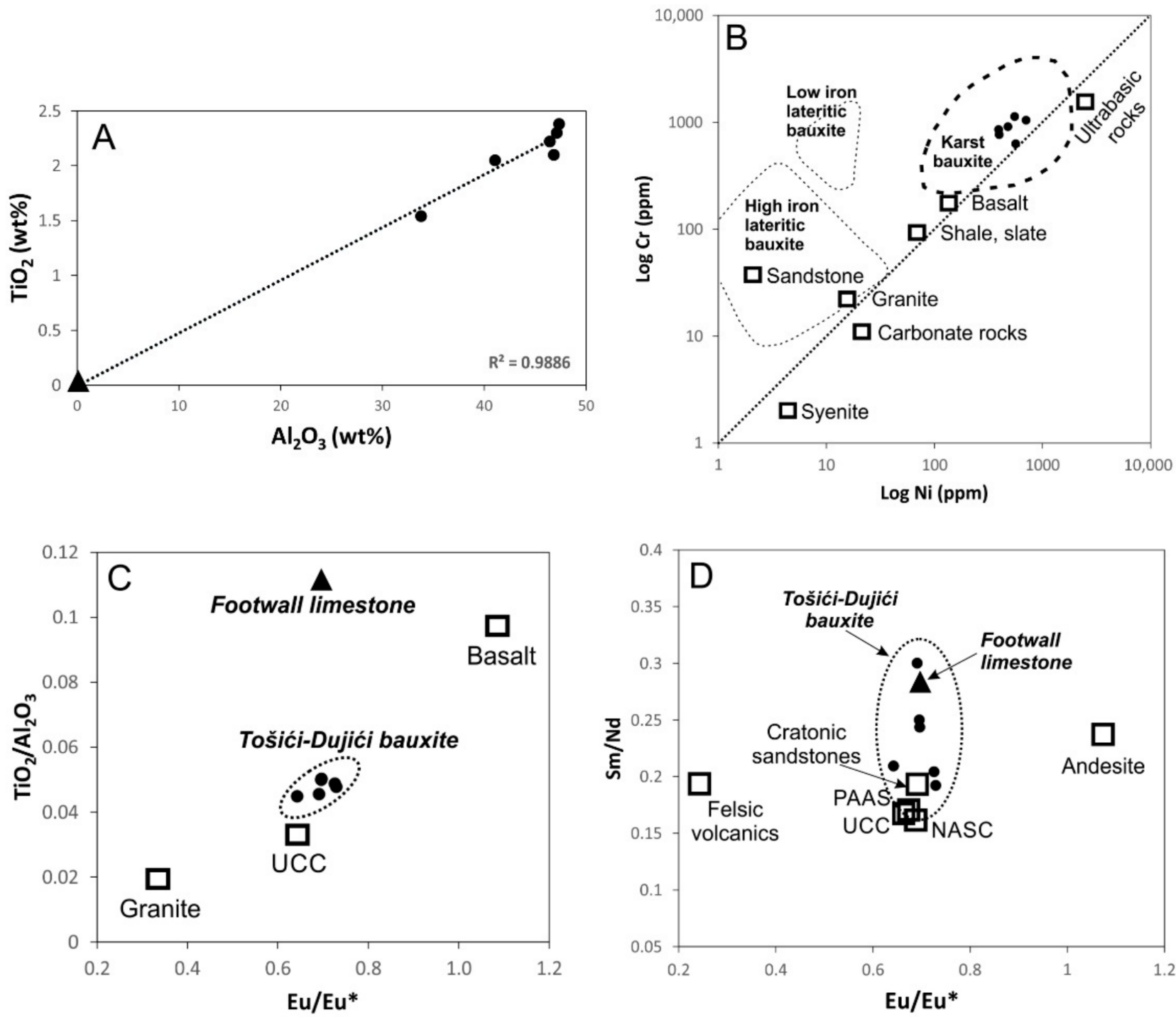

Figure 9. Binary diagrams of selected geochemical data suggesting provenance of detrital material for bauxite of the Tošići-Dujići deposit: (A) - $\mathrm{Al}_{2} \mathrm{O}_{3}$ and $\mathrm{TiO}_{2}$ binary plot showing immobility of $\mathrm{Ti}$ in the bauxite samples $(\bullet)$ and footwall limestone ( $\mathbf{\Delta})$; (B) - $\operatorname{LogNi}$ and $\log C r$ binary diagram showing affinity of the Tošići-Dujići bauxite to the karst bauxite signature; (C)-Eu/ $\mathrm{Eu}^{*}$ and $\mathrm{TiO}_{2} / \mathrm{Al}_{2} \mathrm{O}_{3}$ binary plot showing the bauxite geochemical signature to be closely related to UCC (data from [35]); (D)—Eu/Eu* and $\mathrm{Sm} / \mathrm{Nd}$ binary plot indicating a close connection of the Tošići-Dujići bauxite to UCC, NASC, PAAS, and cratonic sandstones (data from $[35,46]$ ) but also likely heterolithic origin of detrital material suggested by a spread of $\mathrm{Sm} / \mathrm{Nd}$ values.

\subsection{REE Mineralogy}

Two samples with the highest REE abundances (TOS-2 and TOS-3) were checked for presence of REE minerals. REE minerals are hereby considered as those having REE as major constituents occupying dominantly at least one structural position $[47,48]$. REE minerals were revealed only in TOS-3. SEM-EDS analysis confirmed the occurrence of monazite-(Ce) $\left[\mathrm{Ce}\left(\mathrm{PO}_{4}\right)\right]$, xenotime- $(\mathrm{Y})\left[\mathrm{Y}\left(\mathrm{PO}_{4}\right)\right]$ and florencite- $(\mathrm{Ce})\left[\mathrm{CeAl}{ }_{3}\left(\mathrm{PO}_{4}\right)_{2}(\mathrm{OH})_{6}\right]$ (Figure 10). The grains of monazite-(Ce) and xenotime-(Y) seem to be of detrital origin: both minerals present rather preserved crystal morphology, which, however, shows the signs of etching due to chemical weathering and bauxitization (Figure 10A,B). Monazite-(Ce) grains dominate over xenotime-( $(\mathrm{Y})$, and both minerals seem to be deposited as residual detrital phases together with quite frequent zircon grains. High Y content, which is mainly responsible for positive HREE anomaly, is likely to be related to the occurrence of xenotime-(Y). The presence of florencite-(Ce), on the other hand, indicates authigenic 
REE mineralization in the sample, which is triggered by high availability of REE. The florencite-(Ce) sections are anhedral and massive (Figure 10C) while generally of minor size relative to those of the monazite-(Ce) throughout the sample.
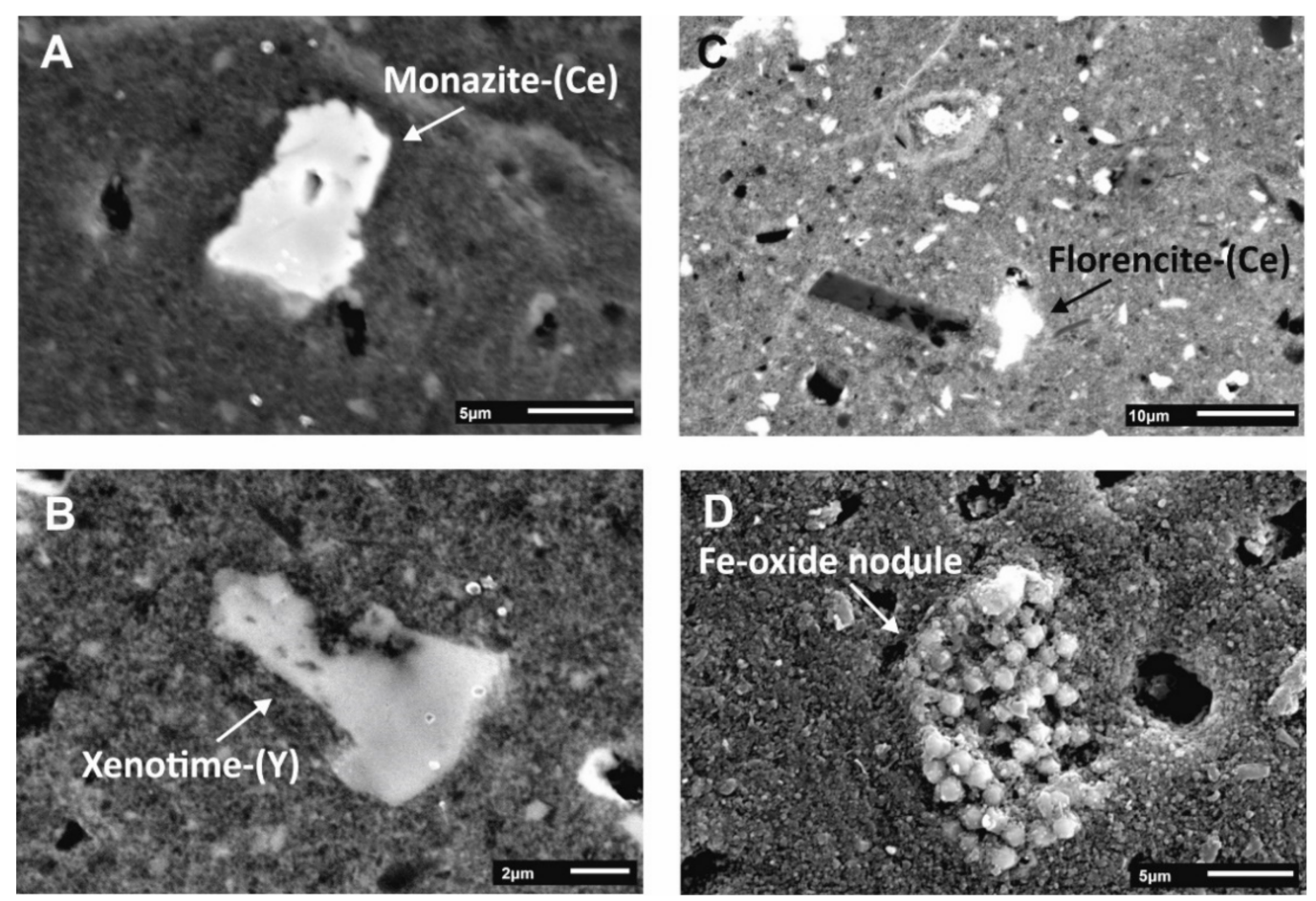

Figure 10. SEM images showing occurrence of REE minerals in the bauxite samples of the Tošići-Dujići deposit: (A)—monazite-(Ce) spotted in TOS-3; (B): xenotime-(Y) observed in TOS-3; (C)-florencite(Ce) occurrence in TOS-3; (D)—Fe-oxide nodule in TOS-2, a potential scavenger of REE.

The sample TOS-2 seems to be devoid of REE minerals, although it is the most enriched in REE among the studied samples. The only trace of a REE mineral can be sometimes observed in very fine aggregates of possibly anhedral monazite-(Ce), clay minerals and Fe-oxyhidroxide. Interestingly, the sample contains many Fe-oxyhydroxide nodules (Figure 10D), which could play a role of traps for REE by scavenging them as they are leached out from upper sections of the deposit [8]. TOS-2 was sampled close to the syncline crest in proximity to the limestone bedrock (Figure 1C). This setting can support formation of $\mathrm{pH}$ barrier with favorable alkaline conditions and concomitant crystallization of REE carbonates like bastnäsite-(Ce), synchysite-(Ce), and parisite-(Ce) in bauxite $[5,7,49]$ as well as in carbonatites [50] and in iron-oxide-copper deposits [51]. The cause for the absence of REE fluorcarbonates could be related to either unfavorable $\mathrm{pH}$ conditions (lower $\mathrm{pH}$ values), as these are suggested by La/Y ratio (Figure 5), or redeposition that could have disturbed stable bauxite profile and leaching/precipitation patterns. The acidic conditions suggested by La/Y ratio, could have been supported by dissolution of pyrite, which was not observed in the samples, however, Fe-oxyhydroxide nodule observed in Figure 10D, largely resembles framboidal pyrite, usually found in coastal sediments [52]. If these pyrite formations had been abundant, their oxidation during bauxitization could have contributed to acidity.

\subsection{Chemical Weathering Intensity}

To understand major and trace elements distribution in a bauxite profile as well as to establish relation to observed mineralogy, particularly occurrence of REE minerals, it is necessary to devise weathering intensity and related patterns of major elements mobilization. One of the most common proxies to elucidate weathering history is chemical index of alteration (CIA). It is calculated using expression CIA $=\left[\mathrm{Al}_{2} \mathrm{O}_{3} /\left(\mathrm{Al}_{2} \mathrm{O}_{3}+\mathrm{CaO}\right.\right.$ 
$+\mathrm{Na}_{2} \mathrm{O}+\mathrm{K}_{2} \mathrm{O}$ )] $\times 100$ [53]. The CIA values of the Tošići-Dujići bauxite samples range 97.87-99.26 (Figure 11A), showing low variability and indicating a significant weathering during bauxitization promoted by humid and warm climate for all bauxite samples. The lowest value is obtained for TOS-2 if all $\mathrm{Ca}$ is calculated as non-carbonate one, and for TOS-3 in a case $\mathrm{Ca}$ is calculated as completely incorporated in carbonate phases. $\mathrm{CaO}$ content is low in all samples $(<1 \%)$, but minor content of calcite cannot be completely excluded. Thus both scenarios (with carbonate and without it) were considered here. Although differences in CIA values for these two samples are not large, they could indicate transfer of mobile elements along topographically distant sections of the deposit. CIA value for the footwall Lower Eocene limestone is below 1, however, when recalculated to non-carbonate fraction, CIA is 76.74 . The latter value sets a more realistic pre-bauxitization baseline of chemical weathering for argillite material potentially derived from the limestone as residual fraction, but likely not the only source for bauxite material.
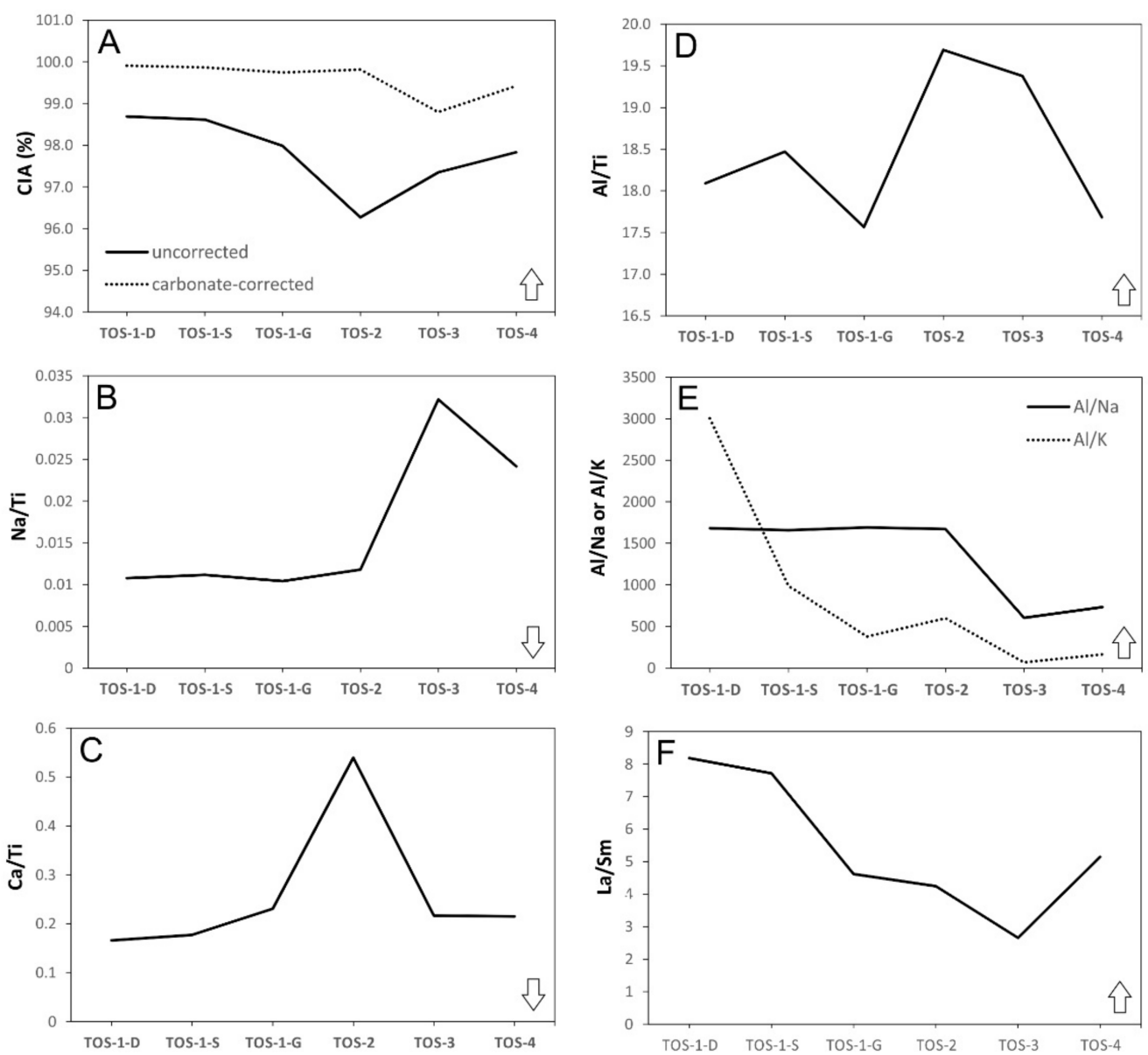

Figure 11. Binary plots of weathering proxies showing intensity of chemical weathering for the bauxite samples from Tošići-Dujići deposit (arrow in bottom right corner of each diagram indicates if smaller $(\downarrow)$ or higher $(\uparrow)$ values imply greater chemical weathering): (A)—chemical index of alteration (CIA); (B)—Na/Ti; (C)—Ca/Ti; (D)—Al/Ti; (E)—Al/Na and $\mathrm{Al} / \mathrm{K}$; (F)—La/Sm.

Other chemical weathering proxies mainly correspond well with CIA values among the samples, showing low variations but confirming element mobility affinity during weathering [54] within the bauxite profile: $\mathrm{Na}$ / Ti values are highest in TOS-3, indicating possible "new" input of the material due to redeposition, however, in general these are very low (Figure 11B), which can suggest strong chemical weathering; $\mathrm{Ca} / \mathrm{Ti}$ ratio is the highest in TOS-2 (Figure 11C), possibly owing to some increase of Ca due to water seeping in low $\mathrm{pH}$ conditions; $\mathrm{Al} / \mathrm{Ti}$ ratios confirm the highest chemical weathering intensity for TOS-2 and TOS-3 (two most enriched REE samples) (Figure 11D), but again $\mathrm{Al} / \mathrm{Na}$ could imply 
possible material input by redeposition in TOS-3 (Figure 11E); $\mathrm{Al} / \mathrm{K}$ ratio demonstrates increased weathering in TOS-1-D/S samples, but also corresponds well to clay component in the samples reflecting occurrence of illite due to decreased $\mathrm{Al} / \mathrm{K}$ values (Figure 11E). Finally, La/Sm ratio is the smallest in the case of TOS-3 (Figure 11F), which might be affected by input of "new" material due to redeposition during bauxitiziation, and, on the other hand, $\mathrm{La} / \mathrm{Sm}$ values are relatively increased in other deposit sections suggesting extreme chemical weathering and concomitant removal of Sm [55].

\subsection{Mass Change Calculations and Relation to Parent Material}

Mass change analysis followed the calculation described in [44] using $\mathrm{TiO}_{2}$ as a basis for calculation since $\mathrm{TiO}_{2}$ was proven to be the most immobile of the elements in the investigated samples (Figures 9A and 12A-F). The calculations were performed after recalculating the bauxite samples to carbonate- and water-free analyses assuming all $\mathrm{Ca}$ is present in the form of calcite.
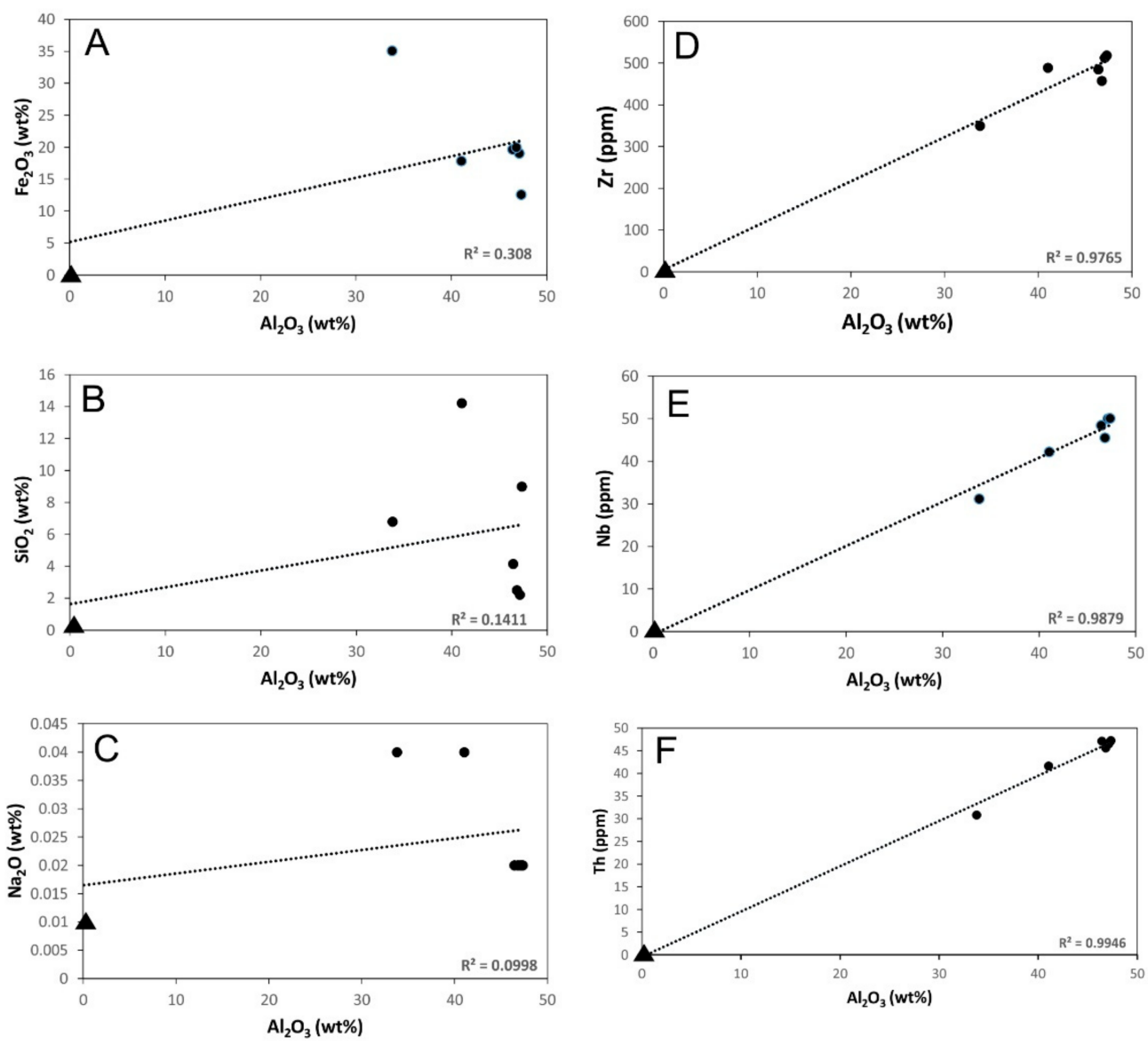

Figure 12. Binary diagrams of major and trace elements vs. $\mathrm{Al}_{2} \mathrm{O}_{3}$ in the Tošići-Dujići bauxite samples $(\bullet)$ and footwall limestone $(\boldsymbol{\Delta})$. Immobile elements are well correlated with $\mathrm{Al}_{2} \mathrm{O}_{3}$ having values $\mathrm{R}^{2}>0.9$ (A) - $\mathrm{Al}_{2} \mathrm{O}_{3}$ vs. $\mathrm{Fe}_{2} \mathrm{O}_{3},(\mathbf{B})-\mathrm{Al}_{2} \mathrm{O}_{3}$ vs. $\mathrm{SiO}_{2},(\mathbf{C})-\mathrm{Al}_{2} \mathrm{O}_{3}$ vs. $\mathrm{Na}_{2} \mathrm{O},(\mathbf{D})-\mathrm{Al}_{2} \mathrm{O}_{3}$ vs. $\mathrm{Zr}$, (E)- $\mathrm{Al}_{2} \mathrm{O}_{3}$ vs. $\mathrm{Nb},(\mathbf{F})-\mathrm{Al}_{2} \mathrm{O}_{3}$ vs. Th).

This procedure assumes that chemical changes from footwall limestone to residual argillite and finally to bauxite are mainly due to dissolution of carbonate. Thus, the mass change calculation can be quite useful to estimate contribution of in situ lithology to bauxite mineralogical and geochemical signature as well as to devise possible input of parent detrital material from other sources.

The calculations show loss in all major components except in aluminum and iron, for which a mass gain was recorded in the Tošići-Dujići deposit (Table 4). Among other 
constituents, particularly Si and Mg were highly mobile and leached out, around 20 and $40 \%$, respectively. Thus, from roughly $100 \mathrm{~g}$ of residual argillite there was 43.98 to $53.44 \mathrm{~g}$ of bauxite formed. An extreme case is TOS-3 with $73.21 \mathrm{~g}$ of bauxite formed from the same argillite mass, which could indicate bauxite to have been derived from more than single source provided by the footwall Eocene limestone. This compares well with the observed textural features of the sample, showing beside pisoidic texture the crevices within bauxite filled with detrital material (Figure $2 \mathrm{G}$ ) as well as various detrital minerals in bauxite matrix (Figure 4). Furthermore, SEM images indicate plentiful detrital zircon, monazite-(Ce) and xenotime-(Y), which are difficult to observe in the sample most abundant in REE (TOS-2). This increase of bauxite mass is mostly on account of roughly triple amount of iron oxide compared with other bauxite samples from the deposit, obviously reflecting additional deposition and postdeposition processes for this section of the deposit, also presented by significantly damaged and fragmented gibbsite grains covered by hematite (Figure $4 \mathrm{D}, \mathrm{F}$ ).

Table 4. Reconstructed composition, enrichment factor (EF), and mass changes for the bauxite samples from the Tošići-Dujići deposit and the argillaceous component of the bedrock limestone.

\begin{tabular}{|c|c|c|c|c|c|c|c|}
\hline & \multicolumn{7}{|c|}{ Reconstructed Composition [\%] } \\
\hline & TOS-1-D & TOS-1-S & TOS-1-G & TOS-2 & TOS-3 & TOS-4 & $\begin{array}{c}\text { TOS-P } \\
\text { (Argillaceous } \\
\text { Component) }\end{array}$ \\
\hline $\mathrm{SiO}_{2}$ & 1.38 & 2.69 & 5.43 & 1.71 & 6.34 & 9.97 & 27.36 \\
\hline $\mathrm{Al}_{2} \mathrm{O}_{3}$ & 29.50 & 30.11 & 28.64 & 32.10 & 31.59 & 28.83 & 12.96 \\
\hline $\mathrm{Fe}_{2} \mathrm{O}_{3}$ & 11.93 & 12.74 & 7.60 & 13.69 & 32.80 & 12.52 & 5.76 \\
\hline $\mathrm{MgO}$ & 0.08 & 0.08 & 0.12 & 0.08 & 0.14 & 0.22 & 41.76 \\
\hline $\mathrm{CaO}$ & 0.00 & 0.00 & 0.00 & 0.00 & 0.00 & 0.00 & 0.00 \\
\hline $\mathrm{Na}_{2} \mathrm{O}$ & 0.01 & 0.01 & 0.01 & 0.01 & 0.04 & 0.03 & 1.44 \\
\hline $\mathrm{K}_{2} \mathrm{O}$ & 0.01 & 0.02 & 0.05 & 0.03 & 0.30 & 0.11 & 1.44 \\
\hline $\mathrm{TiO}_{2}$ & 1.44 & 1.44 & 1.44 & 1.44 & 1.44 & 1.44 & 1.44 \\
\hline $\mathrm{P}_{2} \mathrm{O}_{5}$ & 0.13 & 0.14 & 0.15 & 0.27 & 0.39 & 0.11 & 1.44 \\
\hline $\mathrm{MnO}$ & 0.56 & 0.19 & 0.44 & 0.08 & 0.08 & 0.08 & 2.88 \\
\hline $\mathrm{Cr}_{2} \mathrm{O}_{3}$ & 0.07 & 0.08 & 0.09 & 0.09 & 0.09 & 0.12 & 0.43 \\
\hline Total & 45.10 & 47.52 & 43.98 & 49.51 & 73.21 & 53.44 & 96.90 \\
\hline \multirow[t]{2}{*}{$\mathrm{EF}$} & 0.4550 & 0.4791 & 0.4443 & 0.5015 & 0.7398 & 0.5389 & 1 \\
\hline & \multicolumn{7}{|c|}{ Mass Changes [\%] } \\
\hline $\mathrm{SiO}_{2}$ & -25.97 & -24.67 & -21.92 & -25.65 & -21.02 & -17.38 & 0 \\
\hline $\mathrm{Al}_{2} \mathrm{O}_{3}$ & 16.54 & 17.16 & 15.68 & 19.14 & 18.63 & 15.87 & 0 \\
\hline $\mathrm{Fe}_{2} \mathrm{O}_{3}$ & 6.17 & 6.99 & 1.85 & 7.93 & 27.04 & 6.76 & 0 \\
\hline $\mathrm{MgO}$ & -41.68 & -41.67 & -41.64 & -41.67 & -41.62 & -41.53 & 0 \\
\hline $\mathrm{CaO}$ & 0.00 & 0.00 & 0.00 & 0.00 & 0.00 & 0.00 & 0 \\
\hline $\mathrm{Na}_{2} \mathrm{O}$ & -1.43 & -1.43 & -1.43 & -1.43 & -1.40 & -1.41 & 0 \\
\hline $\mathrm{K}_{2} \mathrm{O}$ & -1.43 & -1.42 & -1.39 & -1.41 & -1.14 & -1.33 & 0 \\
\hline $\mathrm{TiO}_{2}$ & 0.00 & 0.00 & 0.00 & 0.00 & 0.00 & 0.00 & 0 \\
\hline $\mathrm{P}_{2} \mathrm{O}_{5}$ & -1.31 & -1.30 & -1.29 & -1.17 & -1.05 & -1.33 & 0 \\
\hline $\mathrm{MnO}$ & -2.32 & -2.69 & -2.44 & -2.80 & -2.80 & -2.80 & 0 \\
\hline $\mathrm{Cr}_{2} \mathrm{O}_{3}$ & -0.36 & -0.35 & -0.34 & -0.34 & -0.35 & -0.32 & 0 \\
\hline
\end{tabular}

\section{Conclusions}

The bauxite deposit in Tošići-Dujići, Inland Dalmatia, Croatia, shows a significant enrichment in REE, which is also evidenced in some deposit sections by detrital and authigenic REE mineralogy.

Some textural data, particularly in the sample containing REE minerals, suggest redeposition of argillite and bauxite material in some parts of the deposit. Refractory REE minerals, monazite-(Ce) and xenotime-(Y), present partly preserved crystal morphology, which is, however, etched due to extensive chemical weathering and prevailing acidic conditions, as implied by CIA values and La/Y ratio, respectively. Occurrence of florencite-(Ce) 
in the sample, an authigenic REE mineral in bauxites, suggests REE mobilization during chemical weathering and bauxitization, being also evident from peak REE enrichment in local environments of the deposit. Absence of REE carbonate phases in this part of the deposit close to bedrock limestones, confirms absence of $\mathrm{pH}$ barrier to support carbonate formation, as also reinforced by La/Y ratio at the site. Although chemical weathering indicators do not vary at large scale, geochemical indicators suggest changing $\mathrm{pH}$ and Eh conditions during bauxitization, thus enabling both mobilization and later fixation of REE, and making the recorded REE enrichment in the deposit possible.

Geochemical markers clearly imply attachment of bauxite samples to karst bauxite type; however, these also indicate a strong possibility that detrital material could have been derived and transported during Eocene emersion from other sedimentary rocks of the area. The geochemical signature is clearly upper crustal, and a future perspective is to trace the origin of material and place it more exactly in the investigated area.

Author Contributions: Conceptualization, data evaluation, writing-original draft preparation, graphical representations, N.T.; conceptualization, ore geology considerations, graphical representations, A.Č.; sample preparation, thin-section and XRD analysis, M.B.; ore geology and geochemical interpretation, S.M.; mineralogical interpretation, N.I.; field prospecting, deposit data acquisition, N.G.; SEM analysis, M.M. All authors have read and agreed to the published version of the manuscript.

Funding: The research was supported by EIT Raw Materials (European Institute of Innovation and Technology, a body of European Union, under the Horizon 2020) through the fund 17089 REEBAUX - Prospects of REE recovery from bauxite and bauxite residue in the ESEE region.

Acknowledgments: Comments and suggestions provided by the reviewers, which helped to improve the manuscript, are highly appreciated.

Conflicts of Interest: The authors declare no conflict of interest.

\section{References}

1. Marković, S. Hrvatske Mineralne Sirovine; Institut za Geološka Istraživanja: Zagreb, Croatia, 2002; pp. $24-28$.

2. Goodenough, K.M.; Schilling, J.; Jonsson, E.; Kalvig, P.; Charles, N.; Tuduri, J.; Deady, E.A.; Sadeghi, M.; Schiellerup, H.; Müller, A.; et al. Europe's rare earth element resource potential: An overview of REE metallogenetic provinces and their geodynamic setting. Ore Geol. Rev. 2016, 72, 838-856. [CrossRef]

3. Deady, É.A.; Mouchos, E.; Goodenough, K.; Williamson, B.J.; Wall, F. A review of the potential for rare-earth element resources from European red muds: Examples from Seydişehir, Turkey and Parnassus-Giona, Greece. Mineral. Mag. 2016, 80, 43-61. [CrossRef]

4. Deady, E.; Mouchos, E.; Goodenough, K.; Williamson, B.; Wall, F. Rare earth elements in karst-bauxites: A novel untapped European resource? In Proceedings of the ERES2014: 1st European Rare Earth Resources Conference, Milos, Greece, 4-7 September 2014; pp. 364-375.

5. Maksimović, Z.; Pantó, G. Authigenic rare earth minerals in karst-bauxites and karstic nickel deposits. In Rare Earth Minerals, Chemistry, Origin and Ore Deposits; Jones, P.A., Wall, F., Williams, C.T., Eds.; Chapman \& Hall: London, UK, 1996 ; pp. $257-279$.

6. Radusinović, S.; Jelenković, R.; Pačevski, A.; Simić, V.; Božović, D.; Holclajtner-Antunović, I.; Životić, D. Content and mode of occurrences of rare earth elements in the Zagrad karstic bauxite deposit (Nikšić area, Montenegro). Ore Geol. Rev. 2017, 80, 406-428. [CrossRef]

7. Bárdossy, G.; Panto, G.; Varhegyi, G. Rare metals in Hungarian bauxites and conditions of their utilization. Trav. ICSOBA Int. Comm. Study Bauxite Alumina Alum. 1976, 13, 221-231.

8. Boni, M.; Rollinson, G.; Mondillo, N.; Balassone, G.; Santoro, L. Quantitative mineralogical characterization of karst bauxite deposits in the southern Apennines, Italy. Econ. Geol. 2013, 108, 813-833. [CrossRef]

9. Mongelli, G. Ce-anomalies in the textural components of Upper Cretaceous karst bauxites from the Apulian carbonate platform (southern Italy). Chem. Geol. 1997, 140, 69-79. [CrossRef]

10. Mongelli, G.; Boni, M.; Buccione, R.; Sinisi, R. Geochemistry of the Apulian karst bauxites (southern Italy): Chemical fractionation and parental affinities. Ore Geol. Rev. 2014, 63, 9-21. [CrossRef]

11. Ivanović, A.; Sikirica, V.; Sakač, K. Osnovna Geološka Karta SFRJ 1:100.000. Tumač za List Drniš L33-9; Institut za Geološka Istraživanja: Zagreb, Croatia, 1972; Savezni Geološki Institut: Beograd, Yugoslavia, 1978; pp. 31-37.

12. Kruk, B.; Dedić, Ž.; Kovačević Galović, E.; Kruk, L. Osnove Gospodarenja Mineralnim Sirovinama na Području Općine Promina u Šibensko-Kninskoj Županiji, Documentation fund 50/14; Hrvatski geološki institut: Zagreb, Croatia, 2014; pp. 40-57.

13. Sakač, K. O paleoreljefu i pseudopaleoreljefu boksitnih ležišta područja krša. Geološki Vjesn. 1966, 19, 123-129. 
14. Sakač, K. Analiza eocenskog paleoreljefa i tektonskih zbivanja u području Drniša u Dalmaciji s obzirom na postanak ležišta boksita. Geološki Vjesn. 1970, 23, 163-179.

15. Ivanović, A.; Sikirica, V.; Marković, S.; Sakač, K. Osnovna Geološka Karta SFRJ 1:100.000. List Drniš L33-9; Institut za Geološka Istraživanja: Zagreb, Croatia, 1967-1972; Savezni Geološki Institut: Beograd, Yugoslavia, 1977.

16. Bárdossy, G.; Aleva, G.J.J. Lateritic bauxites. Dev. Econ. Geol. 1990, 27, 1-624. [CrossRef]

17. Bárdossy, G. Karst Bauxites: Bauxite Deposits on Karbonate Rocks (Developments in Economic Geology); Elsevier: Amsterdam, The Netherlands, 1982; pp. 1-441.

18. Valeton, I. Bauxites; Elsevier: Amsterdam, The Netherlands, 1972; pp. 1-226.

19. Temur, S.; Kansun, G. Geology and petrography of the Masatdagi diasporic bauxites, Alanya, Antalya, Turkey. J. Asian Earth Sci. 2006, 27, 512-527. [CrossRef]

20. Filho, R.W.N.D.; De Araujo Rocha, G.; Montes, C.R.; Vieira-Coelho, A.C. Synthesis and characterization of boehmites obtained from gibbsite in presence of different environments. Mater. Res. 2016, 19, 659-668. [CrossRef]

21. D'Argenio, B.; Mindszenty, A. Bauxites and related paleokarst: Tectonic and climatic event markers at regional unconformities. Eclogae Geol. Helv. 1995, 88, 459-499.

22. Ling, K.Y.; Zhu, X.Q.; Tang, H.S.; Wang, Z.G.; Yan, H.W.; Han, T.; Chen, W.Y. Mineralogical characteristics of the karstic bauxite deposits in the Xiuwen ore belt, Central Guizhou Province, Southwest China. Ore Geol. Rev. 2015, 65, 84-96. [CrossRef]

23. Davis, C.E.; Hill, V.G. Occurrence of Nordstrandite and its possible significance in Jamaica bauxites. Trav. ICSOBA Int. Comm. Study Bauxite Alumina Alum. 1974, 11, 61-70.

24. Triebold, S.; Luvizotto, G.L.; Tolosana-Delgado, R.; Zack, T.; von Eynatten, H. Discrimination of TiO 2 polymorphs in sedimentary and metamorphic rocks. Contrib. Mineral. Petrol. 2011, 161, 581-596. [CrossRef]

25. Ahmadnejad, F.; Zamanian, H.; Taghipour, B.; Zarasvandi, A.; Buccione, R.; Salamab Ellahi, S. Mineralogical and geochemical evolution of the Bidgol bauxite deposit, Zagros Mountain Belt, Iran: Implications for ore genesis, rare earth elements fractionation and parental affinity. Ore Geol. Rev. 2017, 86, 755-783. [CrossRef]

26. Maksimovic, Z.; Pantó, G. Contribution to the geochemistry of the rare earth elements in the karst-bauxite deposits of Yugoslavia and Greece. Geoderma 1991, 51, 93-109. [CrossRef]

27. Ellahi, S.S.; Taghipour, B.; Zarasvandi, A.; Bird, M.I.; Somarin, A.K. Mineralogy, geochemistry and stable isotope studies of the Dopolan bauxite deposit, Zagros mountain, Iran. Minerals 2016, 6, 11. [CrossRef]

28. Meshi, A.; Hoxha, I.; Milushi, I. Chromitites in the Mirdita ophiolite (Albania): Structure and genetic implications. J. Alp. Geol. 2005, 47, 1-29.

29. Cudennec, Y.; Lecerf, A. The transformation of ferrihydrite into goethite or hematite, revisited. J. Solid State Chem. 2006, 179, 703-709. [CrossRef]

30. Aleva, G.J.J. Laterites: Concepts, Geology, Morphology and Chemistry; InternatiSoil Reference and Information Centre (ISRIC): Wageningen, The Netherlands, 1994; pp. 1-169.

31. Schellmann, W. A new definition of laterite. Mem. Geol. Surv. India 1986, 120, 1-7.

32. Putzolu, F.; Papa, A.P.; Mondillo, N.; Boni, M.; Balassone, G.; Mormone, A. Geochemical characterization of bauxite deposits from the Abruzzi Mining district (Italy). Minerals 2018, 8, 298. [CrossRef]

33. Mameli, P.; Mongelli, G.; Oggiano, G.; Dinelli, E. Geological, geochemical and mineralogical features of some bauxite deposits from Nurra (Western Sardinia, Italy): Insights on conditions of formation and parental affinity. Int. J. Earth Sci. 2007, 96, 887-902. [CrossRef]

34. Radusinović, S.; Papadopoulos, A. The potential for REE and associated critical metals in karstic bauxites and bauxite residue of Montenegro. Minerals 2021, 11, 975. [CrossRef]

35. Taylor, S.R.; McLennan, S.M. The Continental Crust: Its Composition and Evolution; Blackwell: Oxford, UK, 1985.

36. Wakita, H.; Ray, P.; Schmit, R.A. Abundances of 14 rare-earth elements and 12 other trace elements in Apollo 12 samples: Five igneous and one breccia rocks and four soils. In Proceedings of the Second Lunar Science Conference, Houston, TX, USA, 11-14 January 1971; The M.I.T. Press: Cambridge, MA, USA, 1971; Volume 2, pp. 1319-1329.

37. Laufer, F.; Yariv, S.; Steinberg, M. The adsorption of quadrivalent cerium by kaolinite. Clay Miner. 1984, 19, 137-149. [CrossRef]

38. Hanaor, D.A.H.; Sorrell, C.C. Review of the anatase to rutile phase transformation. J. Mater. Sci. 2011, 46, 855-874. [CrossRef]

39. Mondillo, N.; Balassone, G.; Boni, M.; Chelle-Michou, C.; Cretella, S.; Mormone, A.; Putzolu, F.; Santoro, L.; Scognamiglio, G.; Tarallo, M. Rare earth elements (REE) in Al- and Fe-(oxy)-hydroxides in bauxites of provence and languedoc (Southern France): Implications for the potential recovery of rees as by-products of bauxite mining. Minerals 2019, 9, 504. [CrossRef]

40. Lin, P.; Yang, X.; Werner, J.M.; Honaker, R.Q. Application of Eh-pH Diagrams on Acid Leaching Systems for the Recovery of REEs from Bastnaesite, Monazite and Xenotime. Metals 2021, 11, 734. [CrossRef]

41. Haskin, L.A.; Haskin, M.A.; Frey, F.A.; Wildeman, T.R. Relative and Absolute Terrestrial Abundances of the Rare Earths. In Origin and Distribution of the Elements; Ahrens, L.H., Ed.; Pergamon: New York, NY, USA, 1968; pp. 889-912.

42. Mongelli, G. REE and other trace elements in a granitic weathering profile from "Serre", southern Italy. Chem. Geol. 1993, 103, 17-25. [CrossRef]

43. Zamanian, H.; Ahmadnejad, F.; Zarasvandi, A. Mineralogical and geochemical investigations of the Mombi bauxite deposit, Zagros Mountains, Iran. Chemie Erde 2016, 76, 13-37. [CrossRef] 
44. MacLean, W.H.; Bonavia, F.F.; Sanna, G. Argillite debris converted to bauxite during karst weathering: Evidence from immobile element geochemistry at the Olmedo Deposit, Sardinia. Miner. Depos. 1997, 32, 607-616. [CrossRef]

45. Schroll, E.; Sauer, D. Beitrag zur Geochemie von titan, chrom, nikel, cobalt, vanadium und molibdan in bauxitischen gestermenund problem der stofflichen herkunft des aluminiums. Trav. ICSOBA Int. Comm. Study Bauxite Alumina Alum. 1968, 5, 83-96.

46. Condie, K.C. Chemical composition and evolution of the upper continental crust: Contrasting results from surface samples and shales. Chem. Geol. 1993, 104, 1-37. [CrossRef]

47. Levinson, A.A. A system of nomenclature for rare-earth minerals. Am. Mineral. 1966, 51, 152-158.

48. Bayliss, P.; Levinson, A.A. A system of nomenclature for rare-earth mineral species: Revision and extension. Am. Mineral. 1988, 73, 422-423.

49. Johannesson, K.H.; Lyons, W.B.; Stetzenbach, K.J.; Byrne, R.H. The solubility control of rare earth elements in natural terrestrial waters and the significance of PO43- and CO32- in limiting dissolved rare earth concentrations: A review of recent information. Aquat. Geochem. 1995, 1, 157-173. [CrossRef]

50. Broom-Fendley, S.; Brady, A.E.; Wall, F.; Gunn, G.; Dawes, W. REE minerals at the Songwe Hill carbonatite, Malawi: HREEenrichment in late-stage apatite. Ore Geol. Rev. 2017, 81, 23-41. [CrossRef]

51. Schmandt, D.S.; Cook, N.J.; Ciobanu, C.L.; Ehrig, K.; Wade, B.P.; Gilbert, S.; Kamenetsky, V.S. Rare earth element phosphate minerals from the olympic dam $\mathrm{Cu}-\mathrm{U}-\mathrm{Au}-\mathrm{Ag}$ deposit, South Australia: Recognizing temporal-spatial controls on ree mineralogy in an evolved iocg system. Can. Mineral. 2019, 57, 3-24. [CrossRef]

52. Wilkin, R.T.; Barnes, H.L. Formation processes of framboidal pyrite. Geochim. Cosmochim. Acta 1997, 61, 323-339. [CrossRef]

53. Nesbitt, H.W.; Young, G.M. Early Proterozoic climates and plate motions inferred from major element chemistry of lutites. Nature 1982, 299, 715-717. [CrossRef]

54. Wei, G.; Li, X.H.; Liu, Y.; Shao, L.; Liang, X. Geochemical record of chemical weathering and monsoon climate change since the early Miocene in the South China Sea. Paleoceanography 2006, 21, PA4214. [CrossRef]

55. Nesbitt, H.W. Mobility and fractionation of rare earth elements during weathering of a granodiorite. Nature 1979, 279, 206-210. [CrossRef] 